\title{
Post treatment of anaerobically treated brewery effluent using pilot scale horizontal subsurface flow constructed wetland system
}

Ermias Alayu ${ }^{1,2}$ and Seyoum Leta ${ }^{1 *}$ (1)

\begin{abstract}
The anaerobic process is considered to be a sustainable technology for the treatment of wastewaters rich in organic matter mainly due to its lower energy consumption and production of value-added products such as biogas and organic fertilizer. However, it cannot be seen as providing 'complete' environmental solution as its treated effluents would typically not meet the desired discharge limits in terms of residual carbon, nutrients and other pollutants. This has given impetus to subsequent post treatment in order to meet the environmental standards and protect the receiving water bodies and environment. The aim of this study was to evaluate the post-treatment potential of a pilot scale two-stage horizontal subsurface flow constructed wetland (HSSFCW) system planted with Cyperus alternifolius and Typha latifolia, respectively, for enhanced removal of residual carbon and nutrient from an up-flow anaerobic sludge blanket (UASB) reactor treated brewery effluent. A pilot scale two-stage HSSFCW was integrated with the UASB reactor, and its performance efficiency was assessed for the removal of total suspended solids (TSS), chemical oxygen demand (COD), total nitrogen (TN), ammonium-nitrogen $\left(\mathrm{NH}_{4}-\mathrm{N}\right)$, total phosphorous (TP), and orthophosphate $\left(\mathrm{PO}_{4}{ }^{3-}\right)$. Macrophytes aboveground biomass and nutrient accumulation potential were also determined following standard methods. The results from this study showed that Cyperus alternifolius planted CW cell removed 68.5\% TSS, 74.2\% COD, 55.7\% TN, 68.6\% $\mathrm{NH}_{4}-\mathrm{N}, 41.1 \% \mathrm{TP}$ and $48.1 \% \mathrm{PO}_{4}{ }^{3-}$. Moreover, further polishing with Typha latifolia planted CW cell enhanced the removal efficiencies to 89\% TSS, 92\% COD, 83.6\% TN, 92.9\% $\mathrm{NH}_{4}{ }^{-} \mathrm{N}, 74.4 \% \mathrm{TP}$, and 79.5\% $\mathrm{PO}_{4}{ }^{3-}$. Strong linearity and Pearson correlation was found between macrophyte biomass and nutrient accumulation in each CW cell (Cyperus alternifolius: $R^{2}=0.91, r=0.97$ for TN; $R^{2}=0.92, r=0.96$ for TP; and Typha latifolia: $R^{2}=0.96$, $r=0.98$ for TN and TP), and showed substantial nutrient reduction with cumulative nutrient accumulation of 1290 gTNm${ }^{-2}$ and $708.7 \mathrm{gTPm}^{-2}$ in the complete system. The performance of the pilot CW system as a tertiary treatment for brewery wastewater showed that the effluent meets the permissible discharge standards throughout the year excluding phosphorous.
\end{abstract}

Keywords: Horizontal subsurface flow constructed wetland, Cyperus alternifolius, Typha latifolia, Brewery wastewater, Combined macrophyte nutrient uptake potential, Tertiary treatment

\footnotetext{
*Correspondence: seyoum.leta@aau.edu.et; letaseyoum@yahoo.com ${ }^{1}$ Center for Environmental Science, College of Natural and Computational Science, Addis Ababa University, Arat kilo campus, Post - Graduate building, 6th floor, P.O.Box 1176, Addis Ababa, Ethiopia Full list of author information is available at the end of the article
}

\section{Highlight}

- Full scale UASB reactor performance has been evaluated and is effective in COD removal but very limited in nutrient removal capacity.

- The purpose of this study was to assess the post treatment potential of the series connected two-stage HSSFCW for UASB reactor treated brewery effluent. 
- The two-stage HSSFCW polishing totally achieved the national discharge limit for TSS, COD, TN, $\mathrm{NH}_{4}-\mathrm{N}$.

- Consideration should also be given to the use of methane instead of flaring by means of reuse.

\section{Introduction}

In developing countries, only $8 \%$ of wastewater is treated, and reckless disposal of untreated municipal and agroprocessing industrial wastes laden with organic matter, nutrients, and other hazardous chemicals into water bodies and the environment poses ecological and health risks (Nebyou 2011; Worku et al. 2018; Ashekuzzaman et al. 2020). Similarly, discharging of untreated or partially treated high-strength wastewater from brewery also poses contamination of water bodies and the environment (Hultberg and Bodin 2017; Mohan et al. 2018). Brewery industries held an enormous economic position in global beer production greater than 134 billion liters in the past, and become the 5th drinks internationally with an average annual consumption rate of $23 \mathrm{~L}$ per individual (Simate et al. 2011). In Ethiopia, more than 700 million liters of beer were produced per year with $24 \%$ consumption rate (Nebyou 2011). On the other hand, beer production is water demanding process, which consumes $4.5 \mathrm{~L}$ of water per liter of beer production (Karina et al. 2017), and produced 3 to $10 \mathrm{~L}$ of highly polluting effluents (Simate et al. 2011). While, Ethiopian breweries consumed on average $5.6 \mathrm{~m}^{3}$ liter of water per liter of beer production and generate approximately 3.9 $\mathrm{m}^{3}$ wastewater (Worku et al. 2018). In Ethiopia, most of the breweries drain their effluents into rivers and nearby environment, and cause water bodies to stench, discoloration, and oily nature (Belay and Sahile 2013), while effluents used for irrigation can pose soil pollution problem (Oljira et al. 2018). To reduce these problems, environmental authorities are pressuring the breweries to manage their effluents below environmental standards. Few breweries have shown to adopt treatment technologies such as an anaerobic process with the target of capturing energy. However, the final effluent contains residual organic, suspended solid and nutrient concentrations that exceed the national discharge standards (Bulla 2014). Tyagi et al. (2009) have also reported that the anaerobic treatment process was infective to eliminate residual organics, suspended solids, and nutrient to the level of meeting discharge limits. It is evident that anaerobic pretreatment is a known desirable scenario for the robust removal of organic matter from various types of wastewaters (Caliskan et al. 2014), and reduce methane emissions by converting organic matter into value-added products (Karina et al. 2017). Using the aerobic process as a polishing system for the removal of residual organic and nutrient is an energy and chemical-intensive process; requires high operational costs and expensive computerized treatment units; generate secondary pollutants, and its expertise personnel requirement couldn't be affordable for developing countries (Badejo et al. 2014). Even though several other alternative polishing options are available, naturally working constructed wetlands $(\mathrm{CW})$ are gained popularity as an ecofriendly polishing technology, and recently utilized for different anaerobic reactor effluent treatment (Zeb et al. 2013; Jamshidi et al. 2014).

Moreover, the application of $\mathrm{CW}$ integrating with an anaerobic treatment system has a more significant benefit for resource-scarce countries to manage wastewaters with other multiple advantages (El-Khateeb and El-Bahrawy 2013). The anaerobic pretreatment reduce the $C W$ area requirement by 30 to $60 \%$ (Alvarez et al. 2008), avoid chemical or energy requirements (Zeb et al. 2013; Jamshidi et al. 2014), reduce effluent hydraulic retention time (HRT), escaping CW clogging problem, increase the durability of CW (Ayaz et al. 2015), and perform robust organic compound removal through a stepwise microbial degradation process such as hydrolysis, acidogenesis, acetogenesis and methanogenesis into methane $\left(\mathrm{CH}_{4}\right)$, carbon dioxide $\left(\mathrm{CO}_{2}\right)$, and other trace gases (Menzel et al. 2020). While the $\mathrm{CW}$ polishing mitigates a wide variety of residual pollutants such as organic matter, suspended solids, metals, nutrient, and pathogens (Sedaqua 2013), through a variety of physical and biochemical processes (Vymazal 2007). Very few single-stage HSSFCWs were investigated for various types of wastewater post-treatment with promising pollutant reductions (de la Varga et al. 2013; Zeb et al. 2013). However, the treatment of high strength food processing wastewaters using this polishing stage is difficult to produce highquality effluent (Vymazal 2005). Studies recommended a series of interconnected HSSFCW polishing system for enhanced removal of pollutants and discharging high quality effluents (Morino-Solis et al. 2015; Cheng et al. 2010). Studies have also indicated that $C$. alternifolius and T. latifolia individual-based wastewater treatment showed good removal efficiencies for organic matter and nutrient. For instance, C. alternifolius planted HSSFCW removed 95\% COD and 93\% TSS (Sa'at et al. 2017); while T. latifolia removed 92\% TSS, and 79\% COD (Ciria et al. 2005). Terfie and Asfaw (2015) reported up to 82\% $\mathrm{NH}_{4}-\mathrm{N}$ removal efficiency from tannery wastewater using C. alternifolius, and Gebeyehu et al. (2018) reported up to $80 \% \mathrm{TN}, 65 \% \mathrm{NH}_{4}-\mathrm{N}$, and $70 \% \mathrm{PO}_{4}{ }^{3-}$ removal efficiencies from brewery wastewater using T. latifolia. However, there is lack of concrete and reliable scientific data on their combined performance for treating high strength wastewaters such as food processing industries. Studies 
suggested that use of combined macrophytes in the series improves pollutant removals (Rezaie and Salehzadeh 2014) through increasing biomass production, augmenting oxygen availability, microbial activity, and nutrient uptake (Geng et al. 2017).

However, the performance of a given $\mathrm{CW}$ system will largely be influenced by local specific environmental conditions, system design and plant types, among others. Thus, implementing CW for a given wastewater type and local environmental conditions requires local pilot investigations to assess the performance of HSSFCWIs planted with different plant species grown in a given environmental conditions. C. alternifolius and T. latifolia have different growth rates and root structures, and these make for interesting comparisons of the performance of these two plant species in series connected HSSFCWs. Detailed research data on the efficiency of CWs, performance and appropriate set-up are still missing for brewery wastewater treatment. However, efforts have already been made selecting efficient macrophyte species to this particular wastewater (Kenatu 2011; Gebeyehu et al. 2018; Badejo et al. 2014). In addition, a system with a combination of UASB reactor and two-stage HSSFCWs has not yet been applied to brewery wastewater treatment. To generate empirical information to the operational condition of CWs, we developed a series connected twostage HSSFCW system, one planted with C. alternifolius and another planted with T. latifolia, for the enhanced removal of organics and nutrients from anaerobically treated brewery effluent.

\section{Materials and methods}

\section{Experimental location}

A horizontal subsurface flow constructed wetland (HSSFCW) pilot plant was built on the premises of Kombolcha Brewery connected with the existing an up-flow anaerobic sludge blanket (UASB) treatment plant in Kombolcha town, Northern Ethiopia, located at $11^{\circ} 04^{\prime} 42.43^{\prime \prime} \mathrm{N}$ $39^{\circ} 43^{\prime} 34.45^{\prime \prime} \mathrm{E}$ and $1833 \mathrm{~m}$ above sea level, an area with annual average minimum and maximum temperatures varying between $6.1-15.2{ }^{\circ} \mathrm{C}$ and $24.7-30.4{ }^{\circ} \mathrm{C}$, respectively, and mean annual rainfall of $255.7 \mathrm{~mm}$.

\section{Experimental design and setup}

Biological oxygen demand (BOD) is the basis for determining the size of the wetland area required using a first order plug flow model equation proposed by Kickuth, and is commonly used for sizing of HSSFCW system for domestic sewage wastewater treatment (UN-HABITAT 2008). The size of each series connected pilot scale HSSFCW was determined using the daily hydraulic flow rate, $\mathrm{Q}_{\mathrm{d}}\left(0.698 \mathrm{~m}^{3} \mathrm{~d}^{-1}\right)$, influent BOD concentration (223.9 $\left.\mathrm{mgL}^{-1}\right)$, the recommended national discharge standard limit of BOD $\left(60 \mathrm{mgL}^{-1}\right)$, and BOD rate constant $\left(\mathrm{K}_{\mathrm{BOD}}\right)$. The $\mathrm{K}_{\mathrm{BOD}}$ is usually lower, varied in between $0.07-0.1$ $\mathrm{md}^{-1}$. But, according to Vymazal and Kropfelova (2008), many countries used $0.08 \mathrm{md}^{-1}$. The effective aspect ratio $(\mathrm{L} / \mathrm{W})$ of each cell was $5: 1$, which is in agreement with the recommended value of 5:1 (Kadlec and Wallace 2009). The theoretical hydraulic retention time (HRT) was 4 days, which is estimated by Eq. (2) using the average flow through the system $\left(0.698 \mathrm{~m}^{3} \mathrm{~d}^{-1}\right)$, the dimension of each series connected cells $(7.56 \mathrm{~m} \times 1.52 \mathrm{~m})$, the operating water level $(0.45 \mathrm{~m})$, and the initial (clean) porosity of the media (0.27), which was experimentally determined. The hydraulic loading rate (HLR) $\left(\mathrm{md}^{-1}\right)$ is the volume of wastewater loaded per unit surface area of CW, calculated by Eq. (3):

$$
\begin{aligned}
& A_{s}=\frac{Q_{d}\left(\operatorname{In}^{C_{i}}-\operatorname{In}^{C_{e}}\right)}{K_{\mathrm{BOD}}} \\
& \operatorname{HRT}(\text { day })=\frac{\mathrm{LWDP}}{\mathrm{Q}} \\
& \mathrm{HLR}=\frac{\mathrm{Q}}{\mathrm{A}_{\mathrm{s}}}
\end{aligned}
$$

where $Q\left(\mathrm{~m}^{3} \mathrm{~d}^{-1}\right)$ is the hydraulic flow rate, $C_{\mathrm{e}}$ and $C_{\mathrm{i}}$ are the effluent and influent concentrations, $L$ is length of wetland $(\mathrm{m}), W$ is width of wetland $(\mathrm{m}), \mathrm{As}\left(\mathrm{m}^{2}\right)$ is the surface area of the HSSFCW unit, $d(m)$ is the influent flow depth, and $\mathrm{p}$ is the porosity (\%) of the media used.

The experimental setup is shown in Fig. 1 consists of four parts: UASB reactor treatment plant -existing (I); distribution tank (II), two stage HSSFCWs (III) and collection tank (IV). The UASB reactor, distribution tank and the two HSSFCWs were connected by a PVC pipe with control valves. The volume of the existing UASB reactor is $592 \mathrm{~m}^{3}$, which works based on the average hydraulic flow rate of $840 \mathrm{~m}^{3}$ per day. The UASB reactor pre-treatment are consisted of screens, and buffering tank. The screens were used to remove oil and grease, heavy solid materials. The buffering tank was used to balance the $\mathrm{pH}$ variation and flow from operation of the brewing process. One $3000 \mathrm{~L}$ volume distribution tank was used as storage tanks from the UASB reactor plant. The two equally sized series connected wetland cells had $\mathrm{L} \times \mathrm{W} \times \mathrm{D}$ dimensions of $7.56 \mathrm{~m} \times 1.52 \mathrm{~m} \times 0.45 \mathrm{~m}$. The HSSFCW body was made from concretes and well smoothed to avoid any seepage. The outlet pipe was installed $0.35 \mathrm{~m}$ above the floor inside the HSSFCWs and was connected to the collection tank using T- fitting pipe. The series connected HSSFCWs body was made from concretes and the interior region was well insulated. A $15-25 \mathrm{~mm}$ size clay rock media composed of $76.36 \% \mathrm{w} / \mathrm{w}$ 


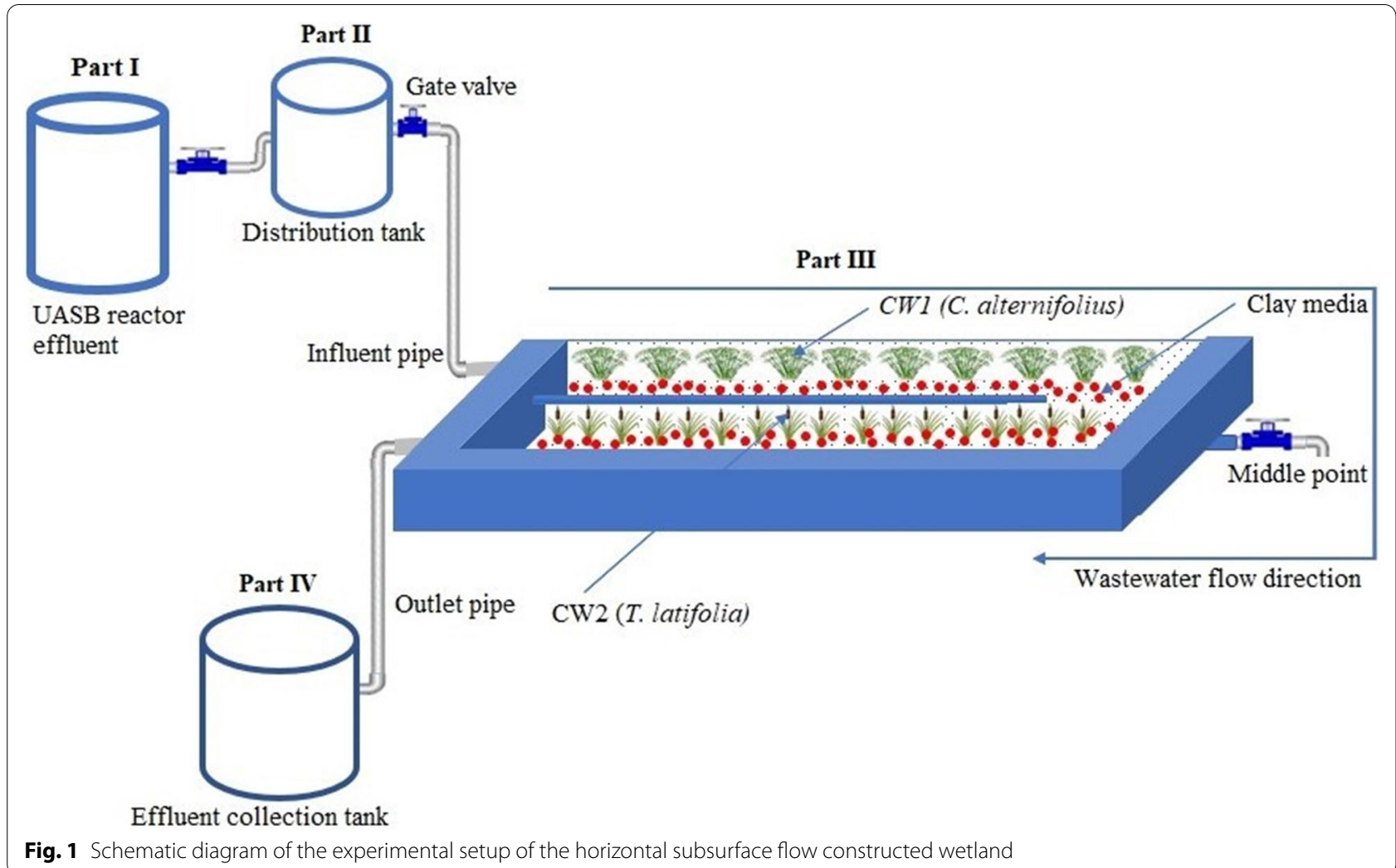

$\mathrm{SiO}_{2}, 13.69 \% \mathrm{w} / \mathrm{w} \mathrm{Al}_{2} \mathrm{O}_{3}, 4.24 \% \mathrm{w} / \mathrm{w} \mathrm{Fe}_{2} \mathrm{O}_{3}, 1.52 \% \mathrm{w} / \mathrm{w}$ $\mathrm{CaO},<0.1 \%$ w/w MgO; obtained from Mitikolo was filled to the depth of $0.45 \mathrm{~m}$. Two locally available macrophytes were collected from Borkena River and identified at Addis Ababa University National Herbarium, and planted in the two-stage HSSFCW unit without mixing orderly in the first and second cells in August 2018. As indicated in Fig. 2ab, the plantation order was preceded by $C$. alternifolius due to its high $\mathrm{pH}$ resistance (Miyazaki et al. 2004), high productivity, relatively strong root system, easy adaptation to organic load changes, salinity tolerance, and high nutrient absorption capacity (Bilgin et al. 2014), followed by T. latifolia due to its short root length (Bonanno and Cirelli 2017), active carbon-producing

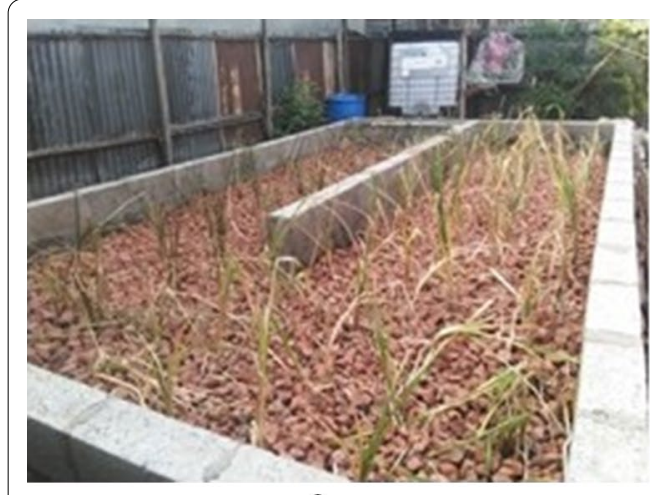

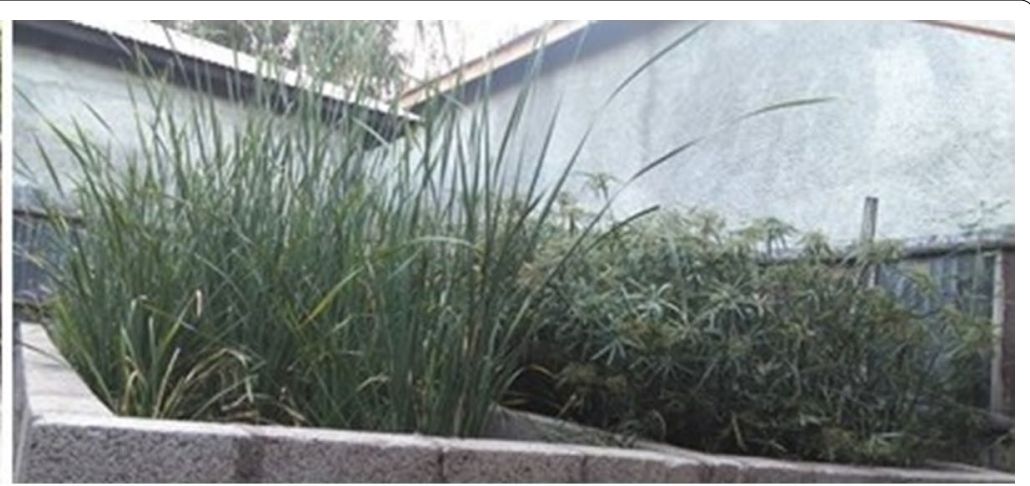

b

Fig. 2 The pilot scale two-stage HSSFCWs planted with C. alternifolius and T. latifolia at the start of operation (a) and fully grown plants during the experimentation (b) 
potential around the rhizosphere for biological activities (Fahlgren 2017), less salinity tolerance, and ability to mitigate nutrient-rich wastewater (Mollard et al. 2013). In addition, these macrophytes biomass use for making floors, animal feed, making roofs, and mattresses (Assefa et al. 2013) and low evapotranspiration rates (Leto et al. 2013) being considered as a selection criterion. The endorsed macrophytes were acclimatized with diluted wastewater (75:25; brewery effluent to clean pipe water ratio) from a reservoir continuously.

\section{Operation of the HSSFCWs}

The operation of the experiment was initiated in January 2018 by pumping a predetermined daily hydraulic flow rate of $0.698 \mathrm{~m}^{3} \mathrm{~d}^{-1}$ through controlling it by a 2-inch gate valve and the performance study was monitored for 1 year, until December 2019. The series connected two-stage HSSFCWs was continuously fed with anaerobically treated effluent from the distribution tank, controlled with the help of a gate valve using a stopwatch and a measuring cylinder at the inlet of the CW. The water depth was maintained at $0.45 \mathrm{~m}$ within the wetland with the aid of fixed outlet pipes. The study was conducted at a HLR of $0.03 \mathrm{md}^{-1}$ with a corresponding hydraulic retention time of 4 days.

\section{Wastewater sampling and quality analysis}

Wastewater samples were collected three times per month from the inlet and outlet of UASB reactor treatment plant, or inlet of CW1, the middle point between the two macrophytes, and outlet of CW2 for 1 year using a pre-cleaned ethylene polyvinyl bottles and transported to the laboratory for immediate analysis. On-site wastewater parameters such as $\mathrm{pH}$, temperature, and dissolved oxygen (DO) were measured using a handheld Intelli$\mathrm{CAL}^{\mathrm{TM}} \mathrm{pH} /$ temperature digital probe $\left(\mathrm{HACH}^{\circledR} \mathrm{HD} 30 \mathrm{~d}\right.$ Flexi, Loveland, USA), and DO meter (YSI 550A, Yellow Springs, OH, USA), respectively. Whereas, the laboratory analyses for parameters such as TSS (oven-dry method), COD (reactor digestion method), TN (persulfate digestion method), $\mathrm{NH}_{4}-\mathrm{N}$ (Nessler Method), TP (Molybdovanadate with Acid persulfate Digestion Method), and $\mathrm{PO}_{4}{ }^{3-}$ (PhosVer $3^{\circledR}$ Method) were measured using a spectrophotometer (DR/890 HACH, Loveland, USA) according to HACH instructions (APHA 1998). The pollutant removal efficiency (RE) and hydraulic loading rate (HLR) were computed following Eqs. (4) and (5) (Juang and Chen 2007):

$$
R E(\%)=\frac{C_{i}-C_{e}}{C_{i}} \times 100
$$

$$
\operatorname{MLR}\left(\mathrm{gm}^{-2} \mathrm{~d}^{-1}\right)=\mathrm{C}_{\mathrm{i}} \times \mathrm{HLR}
$$

\section{Macrophytes biomass and nutrient content measurement}

C. alternifolius and T. latifolia aboveground biomass (AGB) were collected every three months from the HSSFCW cells for 1 year and transferred to the laboratory using plastic bags for dry weight biomass and nutrient content determination. Macrophyte AGB parts were oven-dried at $105{ }^{\circ} \mathrm{C}$ for $24 \mathrm{~h}$ through extending the time until a constant weight was achieved, and weighed (Maqbool and Khan 2013). Dried AGB parts was fine grounded to $<2 \mathrm{~mm}$ sieve. Then, TN was determined using potassium-persulfate decomposition and UV-Vis spectrometry method (APHA 1998). Whereas, TP was determined by digesting $0.5 \mathrm{~g}$ samples in aquaregia for $2 \mathrm{hrs}$ at $90^{\circ} \mathrm{C}$ on a hot plate and determined using Inductively Coupled Plasma (ICP-OES, Arcos spectrophotometer, Germany). The nutrient accumulation $(\mathrm{N})$ in the macrophytes AGB was estimated following Eq. (6).

$$
\mathrm{N}\left(\mathrm{gm}^{-2}\right)=\mathrm{DM}_{\text {macrophyte }} \times \mathrm{C}_{\text {macrophyte }}
$$

where DM is the dry weight biomass of macrophytes $\left(\mathrm{kgm}^{-2}\right) ; C$ is the concentration of TN $\left(\mathrm{gN} \mathrm{kg}^{-1}\right)$ and TP $\left(\mathrm{gPkg}^{-1}\right)$ in the macrophytes.

\section{Data analysis}

The data obtained from the study were analyzed using descriptive and inferential statistical data analysis using Microsoft excel, 2013 and OriginPro2017. The results were expressed in terms of mean and standard deviation values. Results were presented using graphs and tables.

\section{Results and discussion}

\section{Treatment potential of UASB reactor}

Evaluation of treatment performance full scale UASB reactor for Kombolcha brewery effluent showed 58.6\% TSS and 79.3\% COD removal efficiencies at $11 \mathrm{~h}$ HRT with $1170.1 \mathrm{Nm}^{3} \mathrm{~d}^{-1} \mathrm{CH}_{4}$ production. This study result is somewhat higher than reported result of 58\%TSS and $41 \%$ COD removals at $11 \mathrm{~h}$ HRT (Alvarez et al. (2006), and Khan et al. (2014) observed average UASB reactor efficiency of $75 \%$ of TSS and COD removals operated at $8 \mathrm{~h}$ HRT. With regard to nutrient removal, the UASB reactor performance evaluation showed removal efficiencies of $34.4 \% \mathrm{TN}, 32.2 \% \mathrm{TP}$, and $38.9 \% \mathrm{PO}_{4}{ }^{3}$ (Table 1), which are exceeded from Torres and Foresti (2001) reported results of $10-25 \%$ TKN and $10-20 \% \mathrm{PO}_{4}{ }^{3-}$, and El-Khateeb and El-Bahrawy (2013) reported average removal of $11.3 \%$ TKN and $23 \%$ TP. 


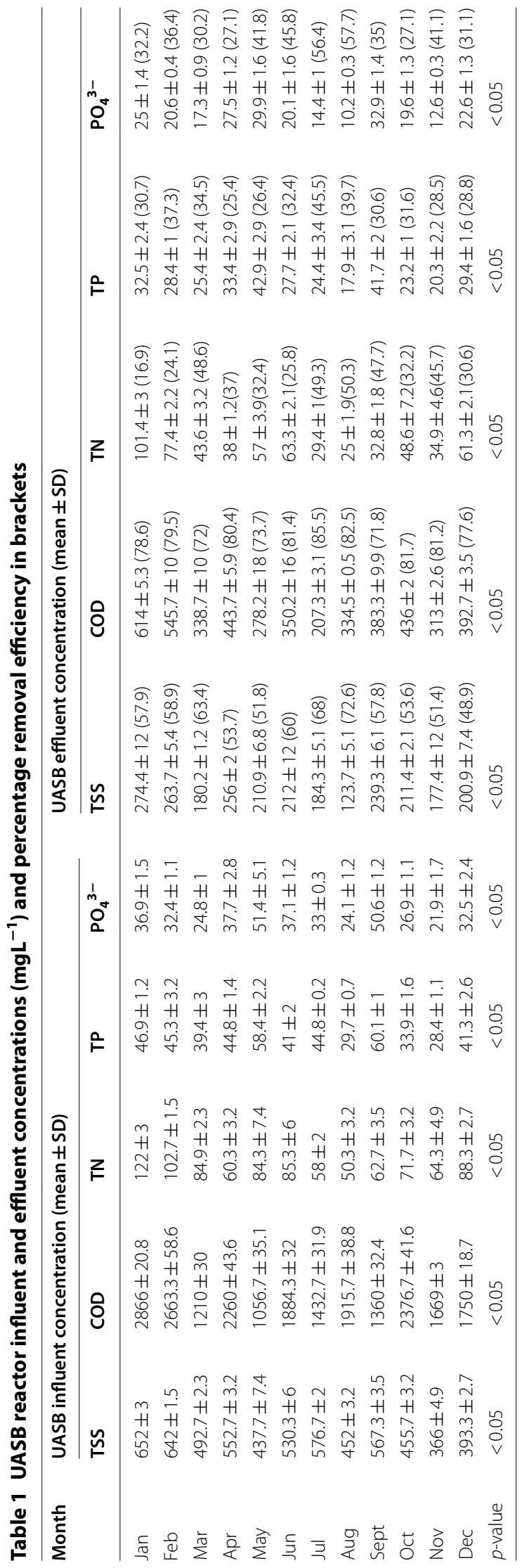


Many studies reported that UASB reactors are limited in removal of nutrients (Cheng et al. 2010; El-Khateeb and El-Bahrawy 2013). The nutrient removal drawback of UASB reactor is associated with mineralization or hydrolysis phenomenon, which increases nutrient concentrations in the anaerobic reactors particularly into ammonia and orthophosphate (Moawad et al. 2009). Overall, characterization of the present UASB reactor brewery effluent suspended solids, and organic matter contents showed substantial fluctuations and exceeded the national discharge standard limit (EEPA 2003). Many research evidences showed that treatment effectiveness of UASB reactor is influenced by several factors such as nature of suspended solids, reactor temperature, organic loading rate, hydraulic retention time, feeding mode or up flow velocity, amount of seed sludge on reactor start up (Hu 2013; Torretta et al. 2017). Anaerobic reactor pollutant abatement efficiency is mainly affected by temperature and $\mathrm{pH}$. Normally, microorganism activity in the anaerobic reactors widely performed at the mesophilic range (i.e., $25-38{ }^{\circ} \mathrm{C}$ ) $\mathrm{pH}$ range of 6.8-7.2 (Saleh and Mahmood 2004). The present UASB reactor influent temperature varied in between $30.6-35.8{ }^{\circ} \mathrm{C}$ with an average value of $34 \pm 1.6{ }^{\circ} \mathrm{C}$, which meets the above mesophilic range and may enhance microbial activities. On contrary, too lower psychrophilic and higher thermophilic conditions cease the growth and activity of methanogens (Rizvi et al. 2015). Whereas, the $\mathrm{pH}$ value was fluctuated between 6.3 and 9.07, with mean value of $7.2 \pm 0.8$, may be due to the use of nitrogen and phosphorous-containing sanitizing chemical agents such as caustic soda, nitric acid, phosphoric acid, etc., and high content of nutrients derived from malts, and yeast cells (Gebeyehu et al. 2018; Amenorfenyo et al. 2019).

\section{Post-treatment potential of two-stage HSSFCWs Characteristics of UASB effluent temperature, $\mathrm{pH}$, and DO}

The UASB reactor effluent average $\mathrm{pH}$ value was varied from 6.9 to 7.9 with an average value of $7.6 \pm 0.3$. But, after polishing with the series connected two-stage HSSFCWs, its value was increased to $7.7 \pm 0.3$ (7.2-8.1) in CW1 and decreased to $7.6 \pm 0.2(7.3-7.9)$ in CW2. In agreement to this study, Merino-Solís et al. (2015) observed $\mathrm{pH}$ value variation in the HSSFCW treatment stages during the treatment of anaerobic reactor effluent. In contradict, Raboni et al. (2014) observed pH reduction in the HSSFCWs during the treatment of the UASB reactor effluent domestic wastewater. However, studies indicated that $C$. alternifolius and T. latifolia based treatment of domestic wastewater neutralizes wastewater $\mathrm{pH}$ value close to 7.0 (Neralla et al. 2010). But, in this study, moderate relationship was found between the inlet and outlet $\mathrm{pH}$ values across the stages and complete system
$\left(R^{2}=0.8, r=0.85\right.$ for CW1; $R^{2}=0.83, r=0.89$ for CW2; and $R^{2}=0.75, r=0.78$ for CW1 + CW2) throughout the study periods (Fig. 3a), may be due to a certain $\mathrm{pH}$ calibration with $30 \% \mathrm{HCl}$ and $50 \% \mathrm{NaOH}$ in the UASB reactor pretreatment stage for the proper functioning of microorganisms in the anaerobic reactor. In CW nitrifying and denitrifying bacteria's activity is influenced by $\mathrm{pH}$, and affects its nitrogen removal mechanism. For instance, $\mathrm{pH}>8.0$, decrease the nitrifying and denitrifying bacteria's activity of the $\mathrm{CW}$ bioreactor. Unlike, in this study, the $\mathrm{pH}$ value meet the optimum $\mathrm{pH}$ ranges of 6.5 to 8.5 , which is safe for both microbial activity and macrophytes growth (Vymazal 2007).

Temperature is another factor that affects organic matter and nitrogen removal mechanisms in the $\mathrm{CW}$ biological reactor when deviates from the favorable range of $19-34{ }^{\circ} \mathrm{C}$. These ranges are suitable for both plant growth and microorganisms growth and activity (Zamora et al. 2019). Hence, measurement of this parameter in the UASB effluent showed a mean value of $32.7 \pm 1.6{ }^{\circ} \mathrm{C}\left(29.9-34.7^{\circ} \mathrm{C}\right)$, which meet the above normal temperature range. Treatment of UASB effluent temperature with two-stage HSSFCWs significantly reduced its value into $25 \pm 2.2{ }^{\circ} \mathrm{C}\left(21.4-28.3^{\circ} \mathrm{C}\right)$ and $20.1 \pm 0.6{ }^{\circ} \mathrm{C}$ (18.7-21. ${ }^{\circ} \mathrm{C}$ ), respectively, for $\mathrm{CW} 1$ and $\mathrm{CW} 2$ (Fig. 3b), and concluded that the HSSFCW treatment system acts as a buffering step. Measurement of the DO level in the UASB effluent was limited, which fluctuated from 0.18 $0.63 \mathrm{mgL}^{-1}$ with an average value of $0.4 \pm 0.1 \mathrm{mgL}^{-1}$. However, when it was treated with two-stage HSSFCWs, the influent DO concentration significant increased to $3.5 \pm 0.6 \mathrm{mgL}^{-1}\left(2.7-5 \mathrm{mgL}^{-1}\right)$ at the outlet of CW1. But, further polishing with $\mathrm{CW} 2$ decreased the CW1 DO concentration to $2.3 \pm 0.6 \mathrm{mgL}^{-1}\left(0.9-3.2 \mathrm{mgL}^{-1}\right)$ followed by CW2 (Fig. 3c), may be due to the difference of macrophytes aeration ability. Overall, the present results revealed that presence of macrophytes can increase the amount of oxygen transfer into the HSSFCWs. In agreement to this study, Zamora et al. (2019) were also observed a significant DO concentration level increment at the outlet of HSSFCWs. Many studies reported that the amount of DO level in the HSSFCWs may be affected by climatic conditions, loading rates, macrophytes ecophysiological and morphological features such as age, biomass, length, diameter, and porosity ( $\mathrm{Li}$ et al. 2011; Dong et al. 2016). Besides, larger biomass of macrophytes influences the release of oxygen (Angassa et al. 2019). Similarly, the greater oxygen availability found in the present two-stage HSSFCWs may be due to the combined oxygen transferring ability and biomass of macrophytes, which agreed with La Bella et al. (2016) reported result of liable oxygen transport by $C$. alternifolius and T. latifolia aeration abilities. Emergent macrophytes such as 

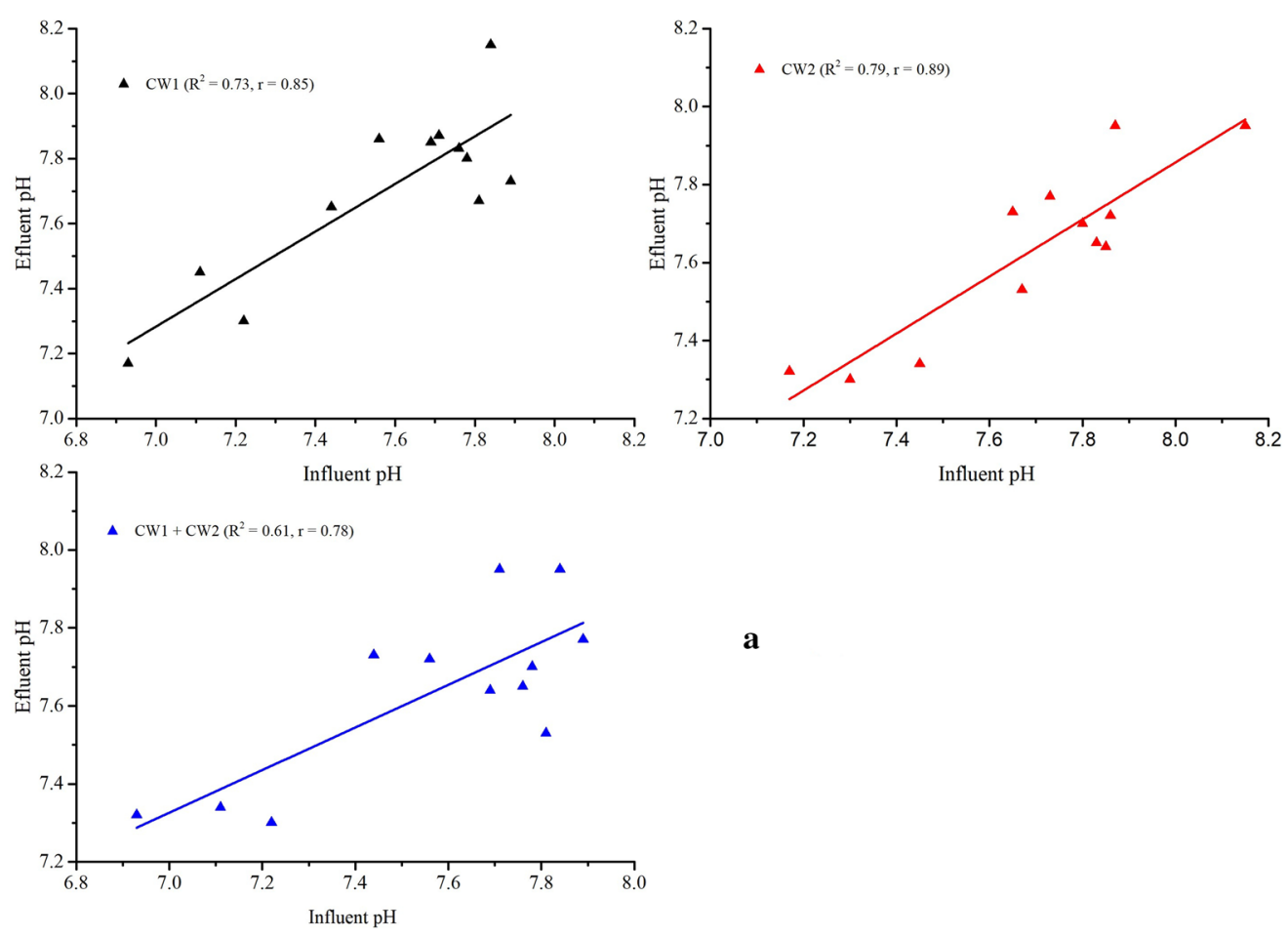

a
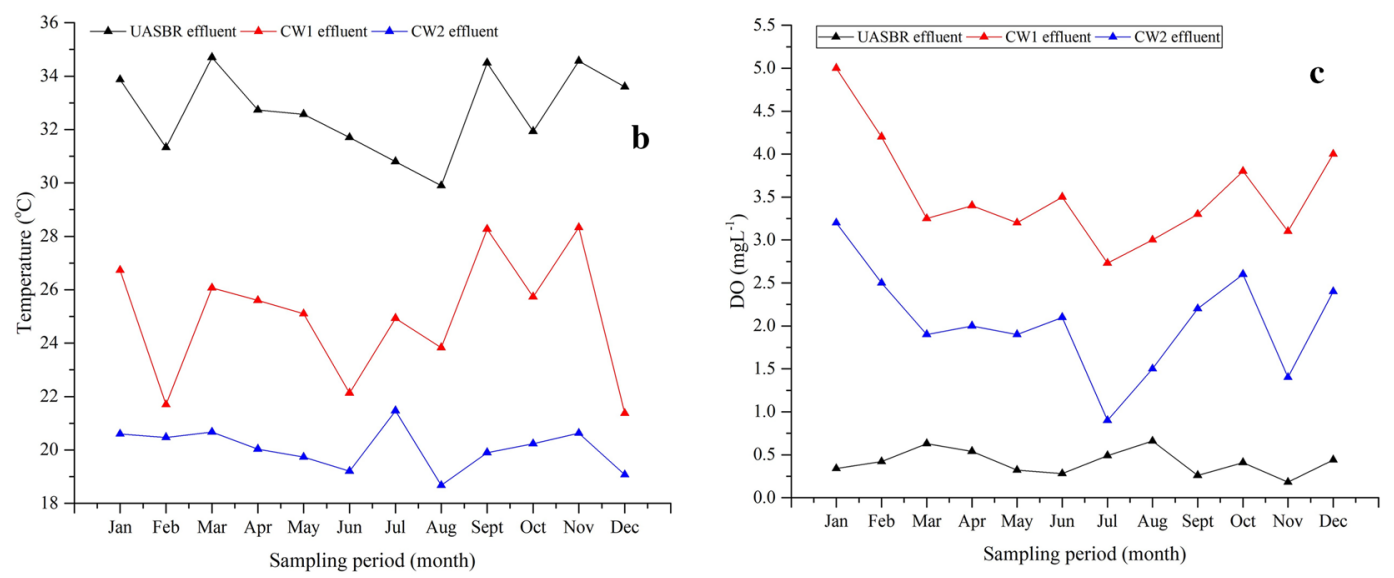

Fig. 3 a Correlation of inlet and outlet pH; variation of influent and effluent (b) temperature, and (c) DO in the series-connected two-stage HSSFCWs

C. alternifolius and $\mathrm{T}$. latifolia have a broad lacunar system, which comprises of $60 \%$ of the tissues are helping in extensive oxygen transport to the rhizosphere (Rehman et al 2017).

\section{The pollutant removal efficiency of the two-stage HSSFCWs \\ TSS and COD removal}

Results from the 1-year operation of the two-stage HSSFCWs revealed high levels of TSS and COD reductions. As displayed in Fig. 4ab and Table 2, the limited removal of UASB reactor TSS and COD pollutants could be compensated by high efficiency in the two-stage HSSFCWs with high-quality effluent that meet the national discharge standard limit. Treatment with CW1 showed an average removal efficiency of $68.5 \pm 6.5 \%$ and $74.2 \pm 5.3 \%$, respectively, for TSS and COD. While further polishing with CW2 removed $66.6 \pm 7 \%$ TSS and $69.8 \pm 5.3 \%$ COD. Enhanced TSS and COD removals were achieved by the complete system throughout the study period (Fig. 4ab). Carballeira et al. (2016) reported that macrophytes have an important role in TSS and COD removals. Likewise, the two macrophytes used in this study contributed favorable TSS and COD removals across the stages. But, 

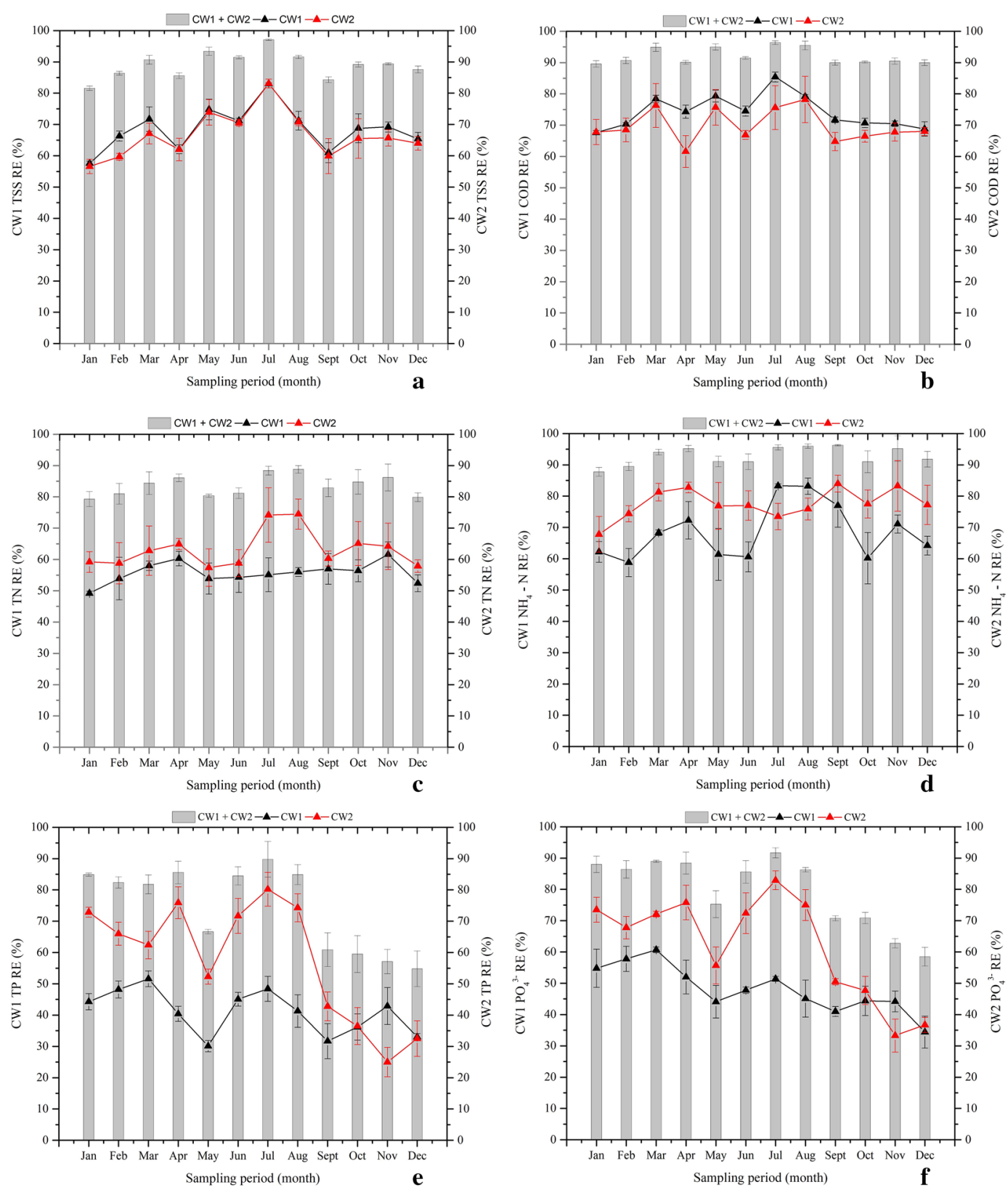

Fig. 4 Removal efficiency variations of (a) TSS, (b) $\mathrm{COD}$, (c) $\mathrm{TN},(\mathbf{d}) \mathrm{NH}_{4}{ }^{-} \mathrm{N},(\mathbf{e}) \mathrm{TP}$ and (f) $\mathrm{PO}_{4}{ }^{3-}$ in the two-stage HSSFCWs

better and almost steadier reductions were achieved by the complete system. During the UASB effluent passage from the inlet to the outlet, the effluent will come in contact with a network of aerobic, anoxic and anaerobic zones around the roots and rhizosphere of the $\mathrm{CW}$ macrophytes that leak oxygen to the media, and cleaned pollutants by the synergies of the physical, chemical, and biological processes in the CWs (UN-HABITAT 2008). Since macrophytes root mat enhances more solid particles adhering, filtration, and sedimentation; and organic matters biodegradation, and consumption by attached anaerobic-aerobic bacteria's (Theophile et al. 2011; Aziz et al. 2015). On the other hand, Panwar and Makvana (2017) found that an increased DO in the effluent leads to greater purity due to the removal of pollutants, which more likely linked to the present study moderate linearity and Pearson correlations found between effluent DO and COD concentrations $\left(R^{2}=0.88, r=0.94\right.$ for CW 1 , and $R^{2}=0.75, r=0.86$ for CW2) (Fig. 5a). Macrophytes root oxygen secretion have a positive effect on pollutant 


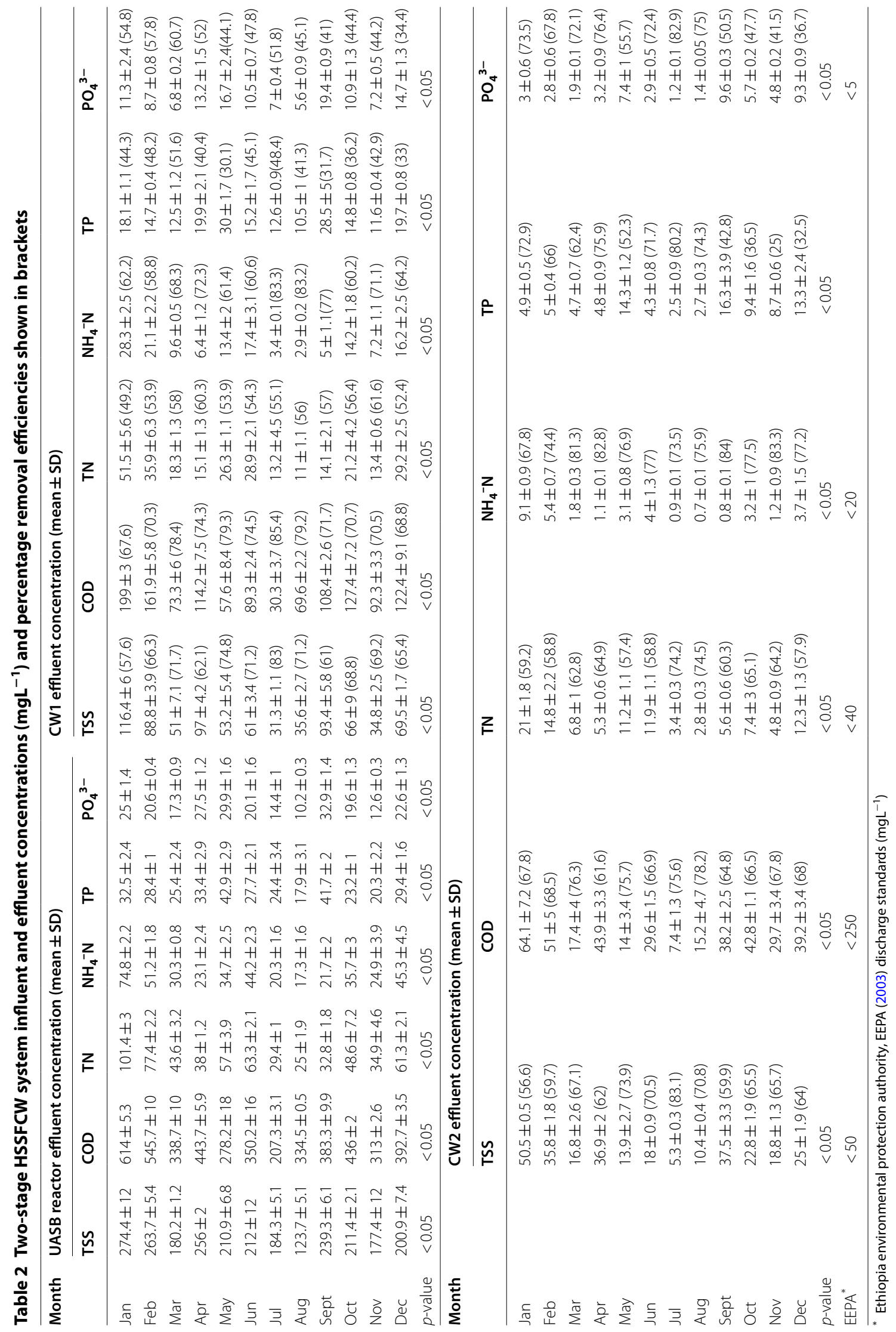


removals in a CWs (Wang et al. 2018) by providing better DO for enhanced aerobic microorganism metabolic activity that reduce organic matters through degradation (Wijaya et al. 2016).

Overall, the complete system showed an average removal efficiencies of $89 \pm 4.1 \% \mathrm{TSS}$ and $92 \pm 2.6 \% \mathrm{COD}$. However, significantly varied TSS and COD removals were observed throughout the study period may be due to the influent pollutant loading and seasonal variations. Da Motta Marques et al. (2001) were noticed a very high significant TSS and COD removal variations due to influent loading effect, in which as with loading increased, TSS and COD removals were decreased. Another study conducted by Chang et al. (2007) were also observed a negative response between the COD mass loading rate and removal efficiency. With regard to the present study, the TSS and COD pollutant loading rate fluctuation influences their removal efficiencies (Fig. 6ab). For instance, when the applied influent loading rate of TSS and COD were $8.3 \mathrm{gTSSm}^{-2} \mathrm{~d}^{-1}$ and $18.6 \mathrm{gCODm}^{-2} \mathrm{~d}^{-1}$, the complete system showed $81.6 \%$ TSS and $89.6 \%$ COD minimal removal efficiencies in January. While the system achieved maximum removal of $97.1 \%$ TSS and $96.4 \% \mathrm{COD}$ when the system loaded with relatively minimum loading of $5.6 \mathrm{gTSSm}^{-2} \mathrm{~d}^{-1}$ and $6.3 \mathrm{gCOD}$ $\mathrm{m}^{-2} \mathrm{~d}^{-1}$ in July. Overall, Fig. 6ab described, as the MLR increased, the TSS and COD removal efficiencies were decreased may be due to loss of suspended solids and organic matters without enough contact. Many studies used single stage HSSFCW systems for post-treatment

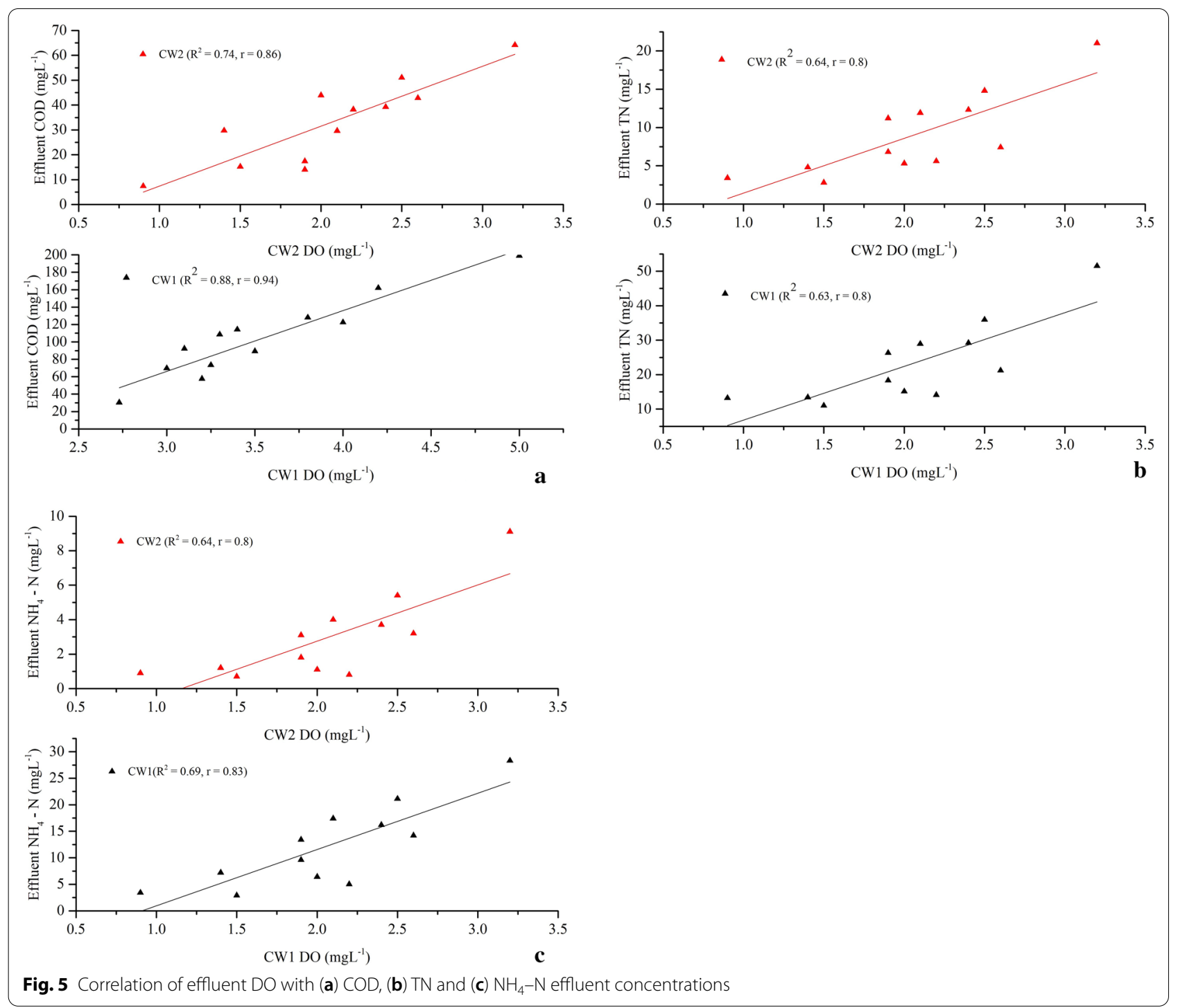



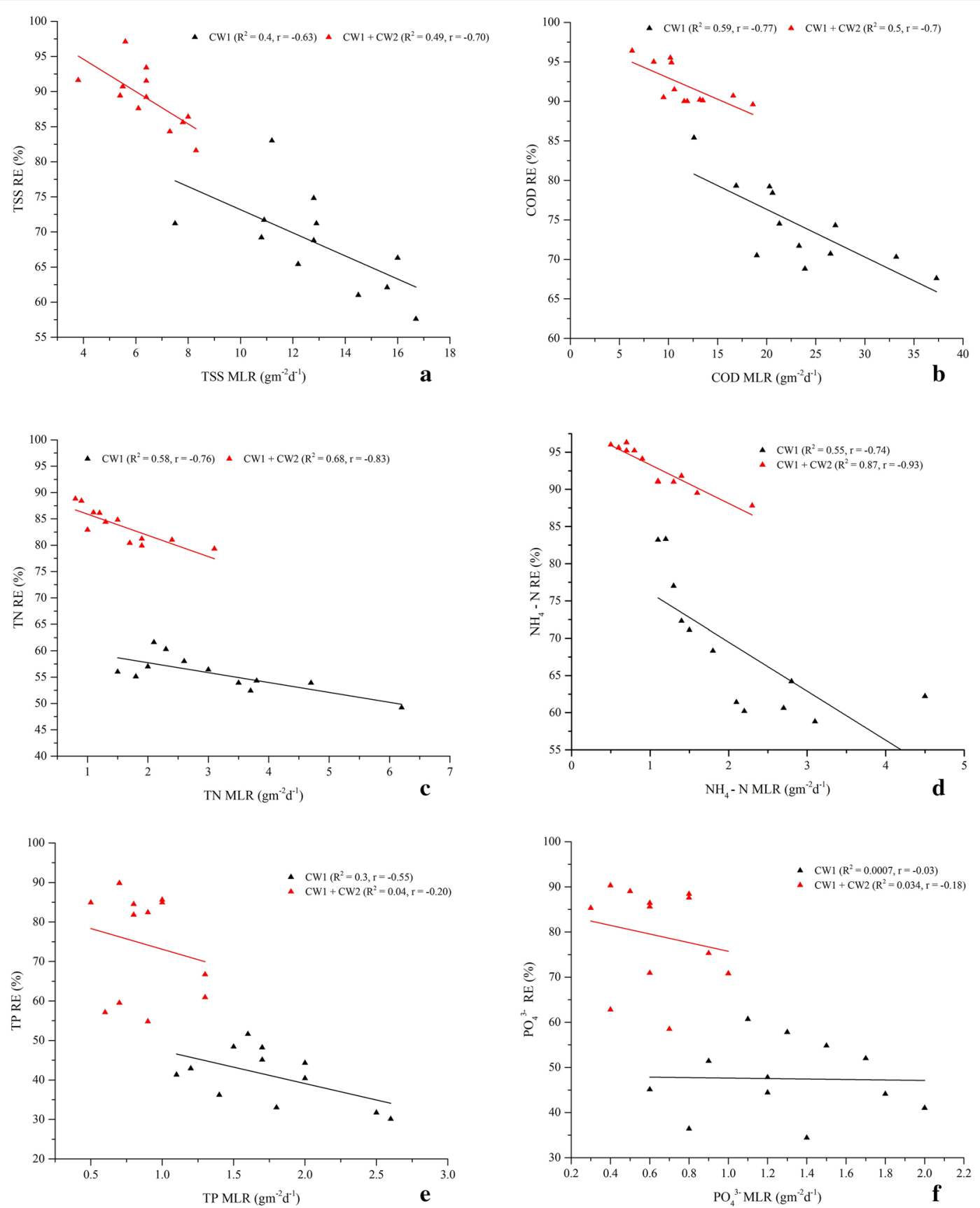

Fig. 6 Relationships of MLR and RE of brewery pollutants in the series-connected two-stage HSSFCWs

of anaerobically treated sewage wastewaters (Table 3 ). De Sousa et al. (2003) were examined the efficiency of a Juncus spp. planted HSSFCWs for polishing UASB reactor sewage wastewater, and reported $70 \%$ to $71 \%$ TSS and $79 \%$ to $86 \%$ COD removals at HRT of 10 days and MLR of $6.64 \mathrm{gCODm}^{-2} \mathrm{~d}^{-1}$. Another study by Von Sperling (2015) was also obtained improved TSS and COD removal of $87.8 \%$ and $84.5 \%$ respectively using a T. latifolia planted
HSSFCWs during treatment of UASB reactor sewage wastewater. As compared to this single stage polishing techniques, the present two-stage HSSFCWs exhibits the superior performance. The system also brought higher treatment efficiency as compared to Cheng et al. (2010) reported results of $79.4 \%$ of TSS and $75.9 \%$ COD removals obtained using a $P$. australis and $P$. stratiotes planted two-stage HSSFCWs for polishing of UASB reactor 


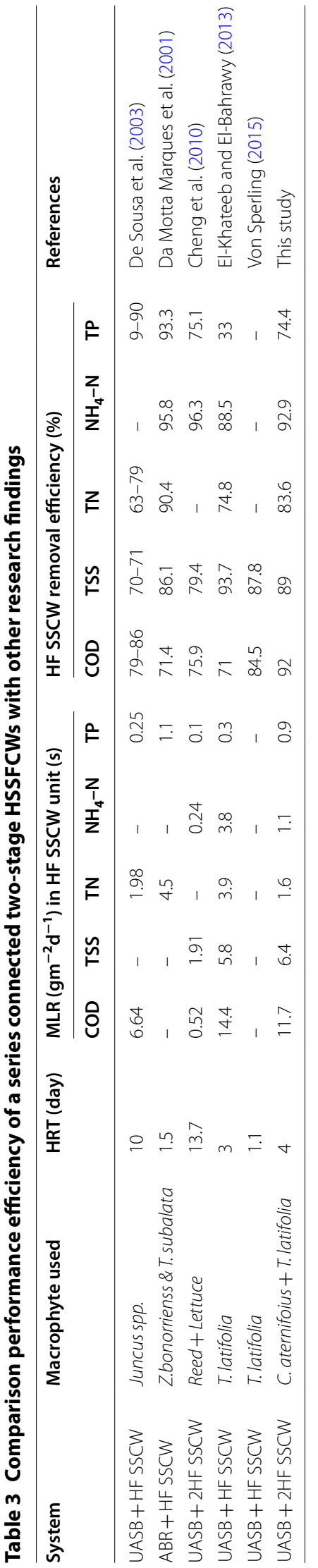


treated mixture of sewage and swine wastewater at HRT of 13.5 days. These marked removal efficiencies may be associated with the concerted action of combined macrophytes through adhering more solid particles, biodegradation, and consumption of organic matters via the action of consortia of anaerobic and aerobic microorganisms located close to the rhizosphere of the macrophytes and in the pores of the substrate (Theophile et al. 2011; Sa'at et al. 2017; La Bella et al. 2016).

\section{$\mathrm{TN}$ and $\mathrm{NH}_{4}-\mathrm{N}$ removal}

Phytoremediation of nutrient rich UASB effluent using two-stage HSSFCWs showed promising TN and $\mathrm{NH}_{4}-$ $\mathrm{N}$ removal efficiencies across the stages. From the data, it is apparent that the CW1 removed $55.7 \pm 3.4 \% \mathrm{TN}$ and $65.5 \pm 8.8 \% \mathrm{NH}_{4}-\mathrm{N}$. While further polishing with CW2 unit drastically decreased the CW1 effluent, and achieved mean removal efficiencies of $63.2 \pm 5.9 \% \mathrm{TN}$ and $77.6 \pm 4.7 \% \mathrm{NH}_{4}-\mathrm{N}$. Moreover, the complete system achieved an improved average removal efficiencies of $83.6 \pm 3.3 \% \mathrm{TN}$ and $92.9 \pm 2.9 \% \mathrm{NH}_{4}-\mathrm{N}$ (Fig. 4cd and Table 2), and met the national discharge standard limits of 40 and $20 \mathrm{mgL}^{-1}$,respectively, may be due to the combined effect of both macrophytes. Previous study by Sa'at et al. (2017) indicated that C. alternifolius based treatment of aerobic palm oil mill effluent at 11 days HRT removed $92 \% \mathrm{NH}_{4}^{-} \mathrm{N}$. another study report by Leto et al. (2013) also showed that $C$. alternifolius based treatment of domestic wastewater removed $65.2 \% \mathrm{TN}$, and $66.7 \%$ $\mathrm{NH}_{4}{ }^{-} \mathrm{N}$. Likewise, the promising removal of $\mathrm{TN}$ and $\mathrm{NH}_{4}-\mathrm{N}$ by CW1 may be due to the relatively high DO concentration that has more positive linear relationships with these pollutant outlet concentrations $\left(R^{2}=0.83\right.$; $r=0.91$ for $\mathrm{TN}$, and $R^{2}=0.84, r=0.91$ for $\mathrm{NH}_{4}^{-} \mathrm{N}$ ) (Fig. 5b), and agreed the finding of La Bella et al. (2016), who observed the vital role of $C$. alternifolius in liable oxygen transport and enables better nitrification due to its larger root mass, deeper root growth and higher aboveground biomass, and good nitrogen absorption ability (Wijaya et al. 2016). Whereas, in the CW2, a weak relationship was found between DO and these pollutants effluent concentrations $\left(R^{2}=0.65 ; r=0.81\right.$ for $\mathrm{TN}$, and $R^{2}=0.64, r=0.81$ for $\mathrm{NH}_{4}{ }^{-} \mathrm{N}$ ) (Fig. $5 \mathrm{c}$ ), implies that it has limited DO transfer ability, and prevails more denitrification process for improved $\mathrm{TN}$ and $\mathrm{NH}_{4}-\mathrm{N}$ removals ( $\mathrm{La}$ Bella et al. 2016). In another study, Bonanno and Cirelli (2017) also reported similar idea that T. latifolia has short root growth, and favors denitrification (Fahlgren 2017).

Nitrogen and ammonia removal efficiencies by the complete system was variable with the greatest amount of $88.8 \pm 1.2 \% \mathrm{TN}$ and $96 \pm 0.2 \% \mathrm{NH}_{4}{ }^{-} \mathrm{N}$ removal obtained in August at relatively lower loading rate of $0.8 \mathrm{gTNm}^{-2} \mathrm{~d}^{-1}$ and $0.6 \mathrm{gNH}_{4}{ }^{-} \mathrm{Nm}^{-2} \mathrm{~d}^{-1}$. Whereas, the lowest $79.3 \pm 2.4 \%$
$\mathrm{TN}$ and $87.8 \pm 1.4 \% \mathrm{NH}_{4}-\mathrm{N}$ removal efficiencies were achieved in January at relatively higher loading rate of $3.1 \mathrm{gTNm}^{-2} \mathrm{~d}^{-1}$ and $2.3 \mathrm{gNH}_{4}-\mathrm{Nm}^{-2} \mathrm{~d}^{-1}$ (Fig. 6cd). Similarly, Gaballah et al. (2020) and Da Motta Marques et al. (2001) were reported a very high $\mathrm{TN}$ and $\mathrm{NH}_{4}-\mathrm{N}$ removal variability due to significant influent loading variations. El-Khateeb and El-Bahrawy (2013) was reported $74.8 \% \mathrm{TN}$ and $88.5 \% \mathrm{NH}_{4}-\mathrm{N}$ removals using a T. latifolia planted HSSFCW unit during the polishing of anaerobic reactor treated domestic wastewater at 3 days HRT and loading rate of $3.9 \mathrm{gTNm}^{-2} \mathrm{~d}^{-1}$ and $3.8 \mathrm{~g} \mathrm{NH}_{4}-\mathrm{N}$ $\mathrm{m}^{-2} \mathrm{~d}^{-1}$. However, $83.6 \% \mathrm{TN}$ and $92.9 \% \mathrm{NH}_{4}-\mathrm{N}$ greater removal results were obtained in the present study at loading rate of $1.6 \mathrm{gTNm}^{-2} \mathrm{~d}^{-1}$ and $1.1 \mathrm{gNH}_{4}-\mathrm{Nm}^{-2} \mathrm{~d}^{-1}$ as compared to many single stage HSSFCW polishing systems mentioned in Table 3 except Da Motta Marques et al. (2001) reported comparable results of $90.4 \% \mathrm{TN}$ and $95 \% \mathrm{NH}_{4}{ }^{-} \mathrm{N}$ removal at 1.5 days $\mathrm{HRT}$ and loading rate of $4.5 \mathrm{gTNm}^{-2} \mathrm{~d}^{-1}$ using a $Z$. bonorriensis and T. subalata planted HSSFCW units during the polishing of anaerobic baffled (ABR) reactor municipal wastewater. Cheng et al. (2010) have also reported similar result of $96.3 \% \mathrm{NH}_{4}-\mathrm{N}$ removal obtained using a $P$. australis and $P$. stratiotes planted two-stage HSSFCW system during polishing of the UASB reactor treated mixture of sewage and swine wastewater at HRT of 13.5 days and loading rate of $4.5 \mathrm{~g} \mathrm{NH}_{4}-\mathrm{N} \mathrm{m}^{-2} \mathrm{~d}^{-1}$. In CWs, enhanced removal of nitrogen is performed by volatilization, ammonification, nitrification, denitrification, plant uptake, and matrix adsorption (UN-HABITAT 2008; Saeed and Sun 2012). Macrophytes nutrient uptake play a significant role in the reduction of nutrients; for instance, Wijaya et al. (2016) indicated C. alternifolius and T. latifolia nitrogen uptake were $0.3 \mathrm{gTNm}^{-2} \mathrm{~d}^{-1}$ and $0.27 \mathrm{gTNm}^{-2} \mathrm{~d}^{-1}$ respectively. But, in this study, measurement of DM of C. alternifolius and T. latifolia were varied between 3.26 and $14.8 \mathrm{kgm}^{-2}$, and 5.21 to $20.26 \mathrm{kgm}^{-2}$, respectively, (Fig. 7a) with an increased TN concentration variations in between 8.62 and $46.23 \mathrm{gTNkg}^{-1}$ and 9.46 to $48.16 \mathrm{gTNkg}^{-1}$ respectively by C. alternifolius and T. latifolia (Fig. 7b). Overall, two-stage HSSFCW phytoremediation process showed enhanced nutrient accumulations varied from 28.1 to $684.2 \mathrm{gTNm}^{-2}$ and 49.3 to $975.7 \mathrm{gTNm}^{-2}$,respectively, C. alternifolius and T. latifolia (Fig. 7c). Strong linearity and Pearson correlations were observed between DM and TN concentration $\left(R^{2}=0.96, r=0.98\right.$ for $C$. alternifolius; $R^{2}=0.99, r=0.99$ for T. latifolia) (Fig. 8ab), and between DM and TN accumulation $\left(R^{2}=0.91, r=0.97\right.$ for C. alternifolius; $R^{2}=0.94, r=0.97$ for $T$. latifolia) (Fig. 8cd). Generally, more than threefold reductions and consistent decline in $\mathrm{TN}$ and $\mathrm{NH}_{4}{ }^{-} \mathrm{N}$ concentrations were achieved by the complete system may be due to the concerted action of the combined macrophytes through 

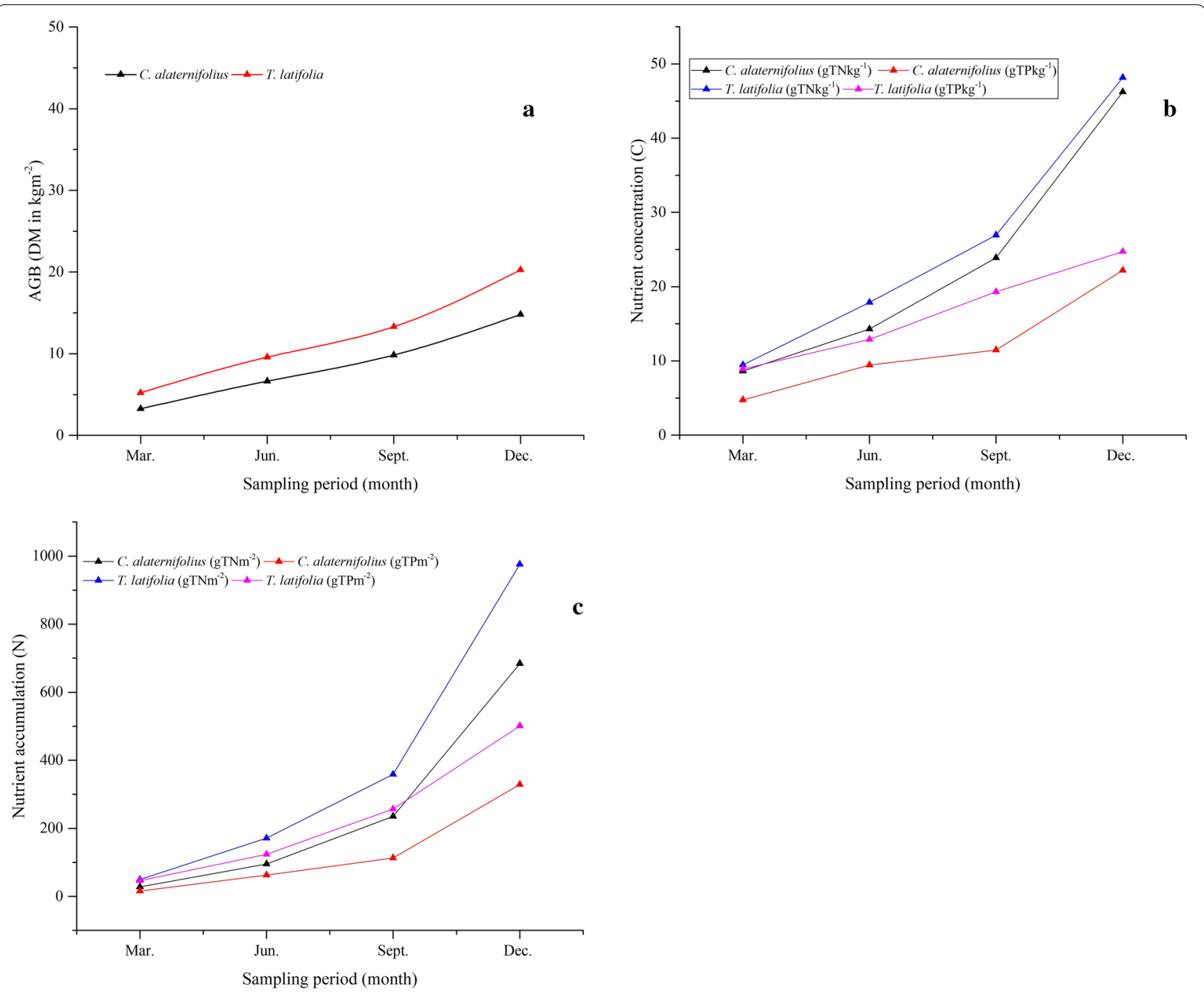

Fig. 7 C. alternifolius and T. latifolia (a) aboveground biomass, (b) nutrient concentration, and (c) Nutrient accumulation

physicochemical and biological processes, and argued with Zhu et al. (2014), who suggested two-stage CW would provide better nitrogen removal.

\section{$\mathrm{TP}$ and $\mathrm{PO}_{4}{ }^{3-}$ removal}

Post-treatment of phosphorus-rich UASB reactor effluent using CW1 resulted mean removal efficiency $41.1 \pm 7 \% \mathrm{TP}$ and $48.1 \pm 7.5 \% \mathrm{PO}_{4}{ }^{3-}$, respectively. Further polishing with CW2 improved the TP and the $\mathrm{PO}_{4}{ }^{3-}$ mean removal efficiencies of $57.7 \pm 19.2 \% \mathrm{TP}$ and $61.9 \pm 16.5 \% \mathrm{PO}_{4}{ }^{3-}$. Further enhanced TP and $\mathrm{PO}_{4}{ }^{3-}$ removal efficiencies of $74.4 \pm 13.3 \%$ and $79.5 \pm 11.3 \%$ were, respectively, achieved by the complete system (Fig. 4ef, Table 2). Overall, significant differences in the removal of TP and $\mathrm{PO}_{4}{ }^{3-}$ were observed between sampling periods for the complete system, with maximum TP removal (> 80\%) from January to August at loading rate varied from 0.5 to $0.9 \mathrm{gm}^{-2} \mathrm{~d}^{-1}$ and $>85 \% \mathrm{PO}_{4}{ }^{3-}$ removal at loading rate varied from 0.3 to $0.7 \mathrm{gm}^{-2} \mathrm{~d}^{-1}$. Also, Gaballah et al. (2020) were also reported that phosphorous removal in a CW system is influenced by loading rate, and conclude that lower loading increase $\mathrm{TP}$ removal in CWs. However, in this study, no correlation was found between loading rate and RE of $\mathrm{TP}$ and $\mathrm{PO}_{4}{ }^{3-}$ (Fig. 6ef). De Sousa et al. (2003) were reported 90\% TP removal using a Juncus sp. planted HSSFCW unit during polishing of anaerobic reactor sewage wastewater at HRT of 10 days and loading rate of $0.25 \mathrm{gTPm}^{-2} \mathrm{~d}^{-1}$. Result comparison of the present study phosphorous removal by the two-stage HSSFCWs was lower than Da Motta Marques et al. (2001) finding, who reported $93.3 \%$ of phosphorous removal at 1.5 days HRT and loading rate of $1.1 \mathrm{gPm}^{-2} \mathrm{~d}^{-1}$ using a Z. bonorriensis and T. subalata planted HSSFCW units 

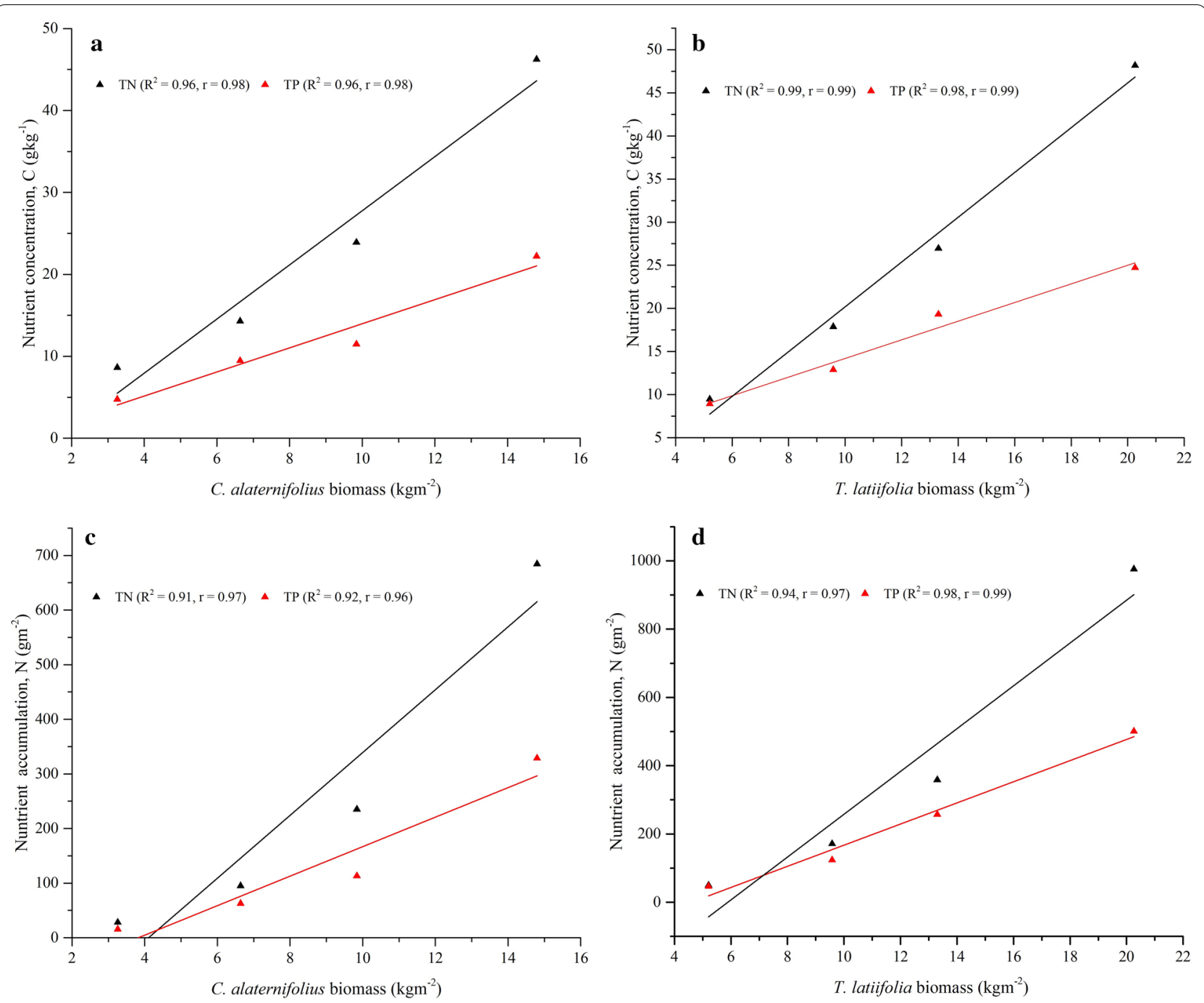

Fig. 8 Correlation of (a) C. aternifolius DM with C, (b) T. latifolia DM with $C_{,}(\mathbf{c})$ C. aternifolius DM with $N$, and (d) T. latifolia DM with N

during polishing of UASB reactor municipal wastewater, and higher than Cheng et al. (2010) reported result of $75.1 \%$ TP removal using a $P$. australis and $P$. stratiotes planted two-stage HSSFCWs during polishing of the UASB reactor mixture of sewage and swine wastewater at HRT of 13.5 days and loading rate of $0.1 \mathrm{gPm}^{-2} \mathrm{~d}^{-1}$ (Table 3). In general, two-stage phytoremediation process showed a promising TP and $\mathrm{PO}_{4}{ }^{3-}$ reduction, which met the national discharge standard limit until August except May. However, after August, almost all, it exceeded the national limit probably due to the saturation of clay media active sites, which decreases the absorption abilities (Ciria et al. 2005). Several studies reported that phosphorous removal in a CW system is dependent on the type of media and macrophytes used. Since these wetland components play a significant role in its removal via media absorption, microbial uptake as well as plant uptake (Badejo et al. 2014). Likewise, Ciria et al. (2005) reviewed that the clay media was the main phosphorous sink and increased its removal efficiency by more than $36 \%$ through adsorption. In another case, the presence of macrophytes were achieved over $60 \%$ of phosphorus removal (Zamora et al. 2019). In this study, analysis of the TP concentration in C. alternifolius and T. latifolia was varied from 4.74 to $22.2 \mathrm{gTPkg}^{-1}$ and 8.92 to $24.71 \mathrm{gTPkg}^{-1}$, respectively (Fig. 7b). Application of these macrophytes in the two-stage HSSFCWs contributed an important role in the reduction of phosphorous through uptake of 129.9 and $231.8 \mathrm{gTPm}^{-2}$ by C. alternifolius and T. latifolia, respectively (Fig. 7c), with cumulative uptake of $708.7 \mathrm{gTPm}^{-2}$. Overall, strong linearity and Pearson correlations were observed between DM and TP concentration $\left(R^{2}=0.96, r=0.98\right.$ for C. alternifolius; $R^{2}=0.98, r=0.99$ for $T$. latifolia) 
(Fig. 8ab), and DM and TP accumulation $\left(R^{2}=0.92\right.$, $r=0.96$ for C. alternifolius; $R^{2}=0.98, r=0.99$ for $T$. latifolia) (Fig. 8cd). Wijaya et al. (2016) and Xu et al. (2017) were also observed good phosphorous uptake abilities of $C$. alternifolius and T. latifolia. In general, a major phosphorous removal mechanism in a CWs are adsorption, precipitation, storage, plant uptake and biotic assimilation (UN-HABITAT 2008).

\section{Conclusion}

Anaerobic digestion is an ideal sustainable pretreatment option for the treatment of high-strength food processing wastewaters through generating valueadded products such as methane and organic fertilizer. Treatment potential evaluation of Kombolcha UASB reactor treatment plant showed $79.3 \% \mathrm{COD}$ removal with a biogas yield of $1170.1 \mathrm{Nm}^{3} \mathrm{~d}^{-1}$. However, its effluent residual organics, suspended solids and nutrient concentrations exceeded the national discharge standard limit. A system with a combination of macrophytes in the series connected two-stage HSSFCWs has been found suitable for the post-treatment of anaerobically treated brewery effluent. This system showed an enhanced pollutant removal efficiencies of $89 \%$, 92\%, $83.6 \%, 92.9 \%, 74.4 \%$, and $79.5 \%$, respectively, for TSS, $\mathrm{COD}, \mathrm{TN}, \mathrm{NH}_{4}-\mathrm{N}, \mathrm{TP}$, and $\mathrm{PO}_{4}{ }^{3-}$, and meets the tolerable national discharge limit, except for phosphorous. Phosphorous removal was also promising for the initial seven-month operations except May, while in the latter operating periods, almost all it exceeded the discharge limit. Overall, the two-stage HSSFCWs planted with $C$. alternifolius followed by T. latifolia is recommended for the post-treatment of the UASB reactor brewery effluent. The study proved that the use of $\mathrm{CW}$ as a posttreatment can turn food processing industrial wastes into clean water use for agriculture purposes.

\section{Abbreviations \\ EEPA: Ethiopian environmental protection authority; APHA: American public health association; HSSFCW: Horizontal subsurface flow constructed wetland; UASB: Up flow anaerobic sludge blanket; HRT: Hydraulic retention time; CW: Constructed wetland; L: Wetland length; W: Wetland width; D: Wetland depth; $A_{s}$ : Wetland surface area; $p$ : Media porosity; $K_{B O D}$ : Biological oxygen demand rate constant; $Q$ : Hydraulic flow rate; $C_{j}$ : Influent concentration; $C_{e}$ : Effluent concentration; RE: Removal efficiency; MLR: Mass loading rate; TSS: Total suspended solids; COD: Chemical oxygen demand; BOD: Biological oxygen demand; $\mathrm{TN}$ : Total nitrogen; $\mathrm{NH}_{4}-\mathrm{N}$ : Ammonia-nitrogen; TP: Total phospho- rous; $\mathrm{PO}_{4}{ }^{3-}$ : Orthophosphate; DO: Dissolved oxygen; AGB: Aboveground biomass; DM: Dry weight biomass.}

\section{Acknowledgments}

The authors thank Kombolcha brewery factory for providing necessary equipment and laboratory facilities; Addis Ababa and Assosa Universities for their financial support.

\section{Authors' contributions}

All authors have equal contributions to this study. EA designed the study, conducted the experiments, data collection and analysis, and wrote the manuscript. SL involved in the study design, supervised the experiment, analyses and interpretation of data and wrote the manuscript. All authors read and approved the final manuscript.

\section{Funding}

This study was supported by the Addis Ababa University from its Thematic Research Grant Scheme and Assosa University.

Availability of data and materials

The data and materials used in this manuscript are available from the corresponding author on request.

\section{Ethics approval and consent to participate}

Not applicable.

\section{Consent for publication}

Not applicable.

\section{Competing interests}

The authors declare that no competing interests.

\section{Author details}

${ }^{1}$ Center for Environmental Science, College of Natural and Computational Science, Addis Ababa University, Arat kilo campus, Post - Graduate building, 6th floor, P.O.Box 1176, Addis Ababa, Ethiopia. ${ }^{2}$ Department of Chemistry, College of Natural and Computational Sciences, Assosa University, P.O.Box 18, Assosa, Ethiopia.

Received: 25 July 2020 Accepted: 21 December 2020

Published online: 28 January 2021

\section{References}

Álvarez JA, Ruíz I, Soto M (2008) Anaerobic digesters as a pretreatment for constructed wetlands. Ecol Eng 33(1):54-67

Álvarez JA, Ruiz I, Gómez M, Presas J, Soto M (2006) Start-up alternatives and performance of a UASB pilot plant treating diluted municipal wastewater at low temperature. Biores Technol 97(14):1640-1649

Angassa K, Leta S, Mulat W, Kloos H, Meers E (2019) Effect of hydraulic loading on bioremediation of municipal wastewater using constructed wetland planted with vetiver grass, Addis Ababa Ethiopia. Nanotechnol Environ Eng 4(1):6

APHA (1998) Standard methods for the examination of water and wastewater. American Public Health Association. Inc., Washington, DC

Amenorfenyo DK, Huang X, Zhang Y, Zeng Q, Zhang N, Ren J, Huang Q (2019) Microalgae brewery wastewater treatment: potentials, benefits, and the challenges. Int J Environ Res Public Health 16(11):1910

Ashekuzzaman SM, Forrestal P, Richards K, Fenton O (2020) Potential loss of nutrients, carbon and metals in simulated runoff associated with dairy processing sludge application. Int J Environ Sci Technol 17:3955-3968. https://doi.org/10.1007/s13762-020-02768-z

Assefa T, Nuria A, Goudar K (2013) Mattress making using typha latifolia and cyperus species of Chefa wetland in Kemissie, Ethiopia: a means for livelihood improvement. Fisheries Aquaculture J 4:2

Ayaz Sç, Aktas O, Akça L, Fındı N (2015) Effluent quality and reuse potential of domestic wastewater treated in a pilot-scale hybrid constructed wetland system. J Environ Manage 156:115-120

Aziz S, Ali M, Asghar S, Ahmed S (2015) Comparative Analysis of Ranunculus muricatus and Typha latifolia as Wetland Plants applied for domestic wastewater treatment in a mesocosm scale study. Int J Biol Biomol Agric Food Biotechnol Eng 9(1):110-118

Badejo AAA, Ndambuki J, Kupolati WK (2014) Performance of Anaerobic Digester-Constructed Wetlands System for Brewery Wastewater Treatment. Proceedings of the IASTED International Conference Environment and Water Resource Management, Gaborone, Botswana. 
Belay A, Sahile S (2013) The effects of dashen brewery wastewater treatment effluent on the bacteriological and physicochemical quality of Shinta River in Gondar, North West Ethiopia. World Environ 3(1):29-36

Bilgin M, Simsek I, Tulun S (2014) Treatment of domestic wastewater using a lab-scale activated sludge/vertical flow subsurface constructed wetlands by using Cyperus alternifolius. Ecol Eng 70:362-365

Bonanno G, Cirelli GL (2017) Comparative analysis of element concentrations and translocation in three wetland congener plants: Typha domingensis, Typha latifolia, and Typha angustifolia. Ecotoxicol Environ Saf 143:92-101

Bulla K (2014) Treatment and Biogas Production Performances Efficiency of St. George Brewery Full Scale Waste Water Treatment System (MSc Thesis]. Addis Ababa (ET): Addis Ababa University).

Caliskan G, Giray G, Gundogdu TK, Azbar N (2014) Anaerobic Biodegradation of Beer Production Wastewater at a Field Scale and Exploitation of Bioenergy Potential of Other Solid Wastes from Beer Production.

Carballeira T, Ruiz I, Soto M (2016) Effect of plants and surface loading rate on the treatment efficiency of shallow subsurface constructed wetlands. Ecol Eng 90:203-214

Chang J, Zhang X, Perfler R, Xu QS, Niu XY, Ge Y (2007) Effect of hydraulic loading rate on the removal efficiency in a constructed wetland in subtropical China. Fresenius Environ Bull 16:1082-1086

Cheng L, Lee H, Lin J, Chou M (2010) Treatment of mixture of sewage and partially treated swine wastewater by a combination of UASB and constructed wetlands. Pract Periodical Hazardous Toxic Radioactive Waste Manag 14:234-239

Ciria MP, Solano ML, Soriano P (2005) Role of macrophyte typha latifolia in a constructed wetland for wastewater treatment and assessment of its potential as a biomass fuel. Biosys Eng 92(4):535-544

Da Motta Marques DML, Leite GR, Giovannini SGT (2001) Performance of two macrophyte species in experimental wetlands receiving variable loads of anaerobically treated municipal wastewater. Water Sci Technol 44(11-12):311-316

de la Varga D, Díaz MA, Ruiz I, Soto M (2013) Heavy metal removal in a UASBCW system treating municipal wastewater. Chemosphere 93:1317-1323

De Sousa JT, Van Haandel A, Lima EPC, Guimaraes AVA (2003) Performance of constructed wetland systems treating anaerobic effluents. Water Sci Technol 48(6):295-299

Dong C, Huang YH, Wang SC, Wang XH (2016) Oxygen supply and wastewater treatment in SubsurfaceFlow constructed wetland mesocosm: role of plant presence. Polish J Environ Studies 25(2):573

El-Khateeb MA, El-Bahrawy AZ (2013) Extensive post treatment using constructed wetland. Life Sci J 10(2):560-568

Ethiopian Environmental Protection Authority, EEPA (2003) Provisional standards for industrial pollution control in Ethiopia, Prepared under the ecologically sustainable development (ESID) project-US. ETH/99/068/ Ehiopia, EPA/UNIDO, Addis Ababa.

Fahlgren D (2017) Genetic variation in common cattail ( Typha latifolia) in southern Sweden. Swedish University of Agricultural Sciences.

Gaballah MS, Abdelwahab O, Barakat KM, Aboagye D (2020) A novel horizontal subsurface flow constructed wetland planted with Typha angustifolia for treatment of polluted water. Environ Sci Pollution Res 27:28449-28462. https://doi.org/10.1007/s11356-020-08669-5

Gebeyehu A, Shebeshe N, Kloos H, Belay S (2018) Suitability of nutrients removal from brewery wastewater using hydroponic technology with Typha latifolia. BMC Biotechnol 18:1-13

Geng Y, Han W, Yu C, Jiang Q, Wu J, Chang J (2017) Effect of plant diversity on phosphorus removal in hydroponic microcosms simulating floating constructed wetlands. Ecol Eng 107:110-119

$\mathrm{Hu} J$ (2013) Anaerobic digestion of sludge from brackish aquaculture recirculation system: CSTR performance, analysis of methane potential and phosphatase, struvite crystallization.

Hultberg M, Bodin H (2017) Fungi-based treatment of brewery wastewaterbiomass production and nutrient reduction. Appl Microbiol Biotechnol 101:4791-4798

Jamshidi S, Akbarzadeh A, Woo KS, Valipour A (2014) Wastewater treatment using integrated anaerobic baffled reactor and Bio-rack wetland planted with. J Environ Health Sci Eng 12:1-12

Juang DF, Chen PC (2007) Treatment of polluted river water by a new constructed wetland. Int J Environ Sci Technol 4(4):481-488

Kadlec RH, Wallace SD (2009) Treatment wetlands, 2nd edn. CRC Press, Boca Raton
Kenatu A (2011) Evaluation of the performance of constructed wetland system for treatment of brewery wastewater. Master's thesis, Addis Ababa Institute of Technology University, Addis Ababa

Karina M, Jos H, Sequinel R, Pioneiro R (2017) Treatment of brewery wastewater and its use for biological production of methane and hydrogen. Int J Hydrogen Energy 42:26243-26256

Khan AA, Gaur RZ, Mehrotra I, Diamantis V, Lew B, Kazmi AA (2014) Performance assessment of different STPs based on UASB followed by aerobic post-treatment systems. J Environ Health Sci Eng 12(1):43

La Bella S, Tuttolomondo T, Leto C, Bonsangue G, Leone R, Virga G, Licata M (2016) Pollutant removal efficiency of a pilot-scale Horizontal Subsurface Flow in Sicily (Italy) planted with Cyperus alternifolius L. and Typha latifolia $\mathrm{L}$. and reuse of treated wastewater for irrigation of Arundo donax L. for pellet production - Results of two-year tests under Mediterranean climatic conditions. Desalination Water Treatment 57(48-49):22743-22763

Leto C, Tuttolomondo T, La Bella SL, Leone R, Licata M (2013) Effects of plant species in a horizontal subsurface flow constructed wetland-phytoremediation of treated urban wastewater with Cyperus alternifolius L. and Typha latifolia L. in the West of Sicily (Italy). Ecol Eng 61:282-291

Li H, Ye ZH, Wei ZJ, Wong MH (2011) Root porosity and radial oxygen loss related to arsenic tolerance and uptake in wetland plants. Environ Pollut 159(1):30-37

Maqbool C, Khan BA (2013) Biomass and Carbon Content of Emergent Macrophytes in Lakes Manasbal, Kashmir: Implication for Carbon Capture and Sequestration. Int J Sci Res Publications 3:1

Merino-Solís ML, Villegas E, De Anda J, López-López A (2015) The effect of the hydraulic retention time on the performance of an ecological wastewater treatment system: an anaerobic filter with a constructed wetland. Water 7(3):1149-1163

Menzel T, Neubauer P, Junne S (2020) Role of microbial hydrolysis in anaerobic digestion. Energies 13(21):5555

Miyazaki A, Takeuchi T, Nakamura H, Yamamoto Y (2004) Soil Science and plant nutrition characteristics of nutrient absorption and water purification in some plant species grown by floating culture system. Soil Sci Plant Nutr 50(3):357-363

Moawad A, Mahmoud UF, El-Khateeb MA, El-Molla E (2009) Coupling of sequencing batch reactor and UASB reactor for domestic wastewater treatment. Desalination 242:325-335

Mohan S, Vivekanandhan V, Sivakumar R (2018) Performance of an up-flow anaerobic sludge blanket reactor ( UASB reactor) in the treatment of brewery effluent. Am J Eng Res 5:351-356

Mollard FPO, Roy M, Foote AL (2013) Typha latifolia plant performance and stand biomass in wetlands affected by surface oil sands mining. Ecol Eng 58:26-34

Nebyou S (2011) Technical efficiency analysis of the Ethiopian brewery. MSc Thesis, Addis Ababa University, Ethiopia

Neralla S, Weaver RW, Varvel TW, Lesikar BJ (2010) Phytoremediation and on-site treatment of septic effluents in sub-surface flow constructed wetlands. Environ Technol 20:1139-1146

Oljira T, Muleta D, Jida M (2018) Potential applications of some indigenous bacteria isolated from polluted areas in the treatment of brewery effluents. Biotechnology research international, 2018.

Panwar RS, Makvana KS (2017) Reed-Phragmites karka based constructed wetland for the treatment of domestic wastewater in Ujjain city of Central India. Int J Sci Res Biol Sci 4:1-5

Raboni M, Gavasci R, Urbini G (2014) UASB followed by sub-surface horizontal flow phytodepuration for the treatment of the sewage generated by a small rural community. Sustainability 6(7000):6998-7012

Rehman F, Pervez A, Khattak BN, Ahmad R (2017) Constructed wetlands: perspectives of the oxygen released in the rhizosphere of macrophytes. Clean: Soil, Air, Water. https://doi.org/10.1002/clen.201600054

Rezaie H, Sahlezadeh M (2014) Performance removal nitrate and phosphate from treated municipal wastewater using Phragmites australis and Typha latifolia aquatic plants. J Civil Eng Urban 4(3):315-321

Rizvi H, Ahmad N, Abbas F, Bukhari IH, Yasar A, Ali S, Riaz M (2015) Start-up of UASB reactors treating municipal wastewater and effect of temperature/ sludge age and hydraulic retention time (HRT) on its performance. Arabian J Chem 8(6):780-786

Sa'at SKM, Zaman NQ, Yusoff SM, Ismail HA (2017) Investigation of the potential of Cyperus alternifolius in the phytoremediation of palm oil mill effluent. In AIP Conference Proceedings 1892(1):040009. AIP Publishing LLC. 
Saeed T, Sun G (2012) A review on nitrogen and organics removal mechanisms in subsurface flow constructed wetlands: dependency on environmental parameters, operating conditions, and supporting media. J Environ Manage 112:429-448

Saleh MM, and Mahmood UF (2004) Anaerobic digestion technology for industrial wastewater treatment. In Proceedings of the eighth international water technology conference, IWTC, Alexandria, Egypt (pp. 26-28).

Sedaqua V (2013) Heavy metal removal in a UASB-CW system treating municipal wastewater. Chemosphere 93:1317-1322

Simate GS, Cluett J, lyuke SE, Musapatika ET, Ndlovu S, Walubita LF, Alvarez AE (2011) The treatment of brewery wastewater for reuse : state of the art the treatment of brewery wastewater for reuse: state of the art. Desalination 273:235-247

Tyagi VK, Khan AA, Kazmi AA, Mehrotra I, Chopra AK (2009) Slow sand filtration of UASB reactor effluent: a promising post-treatment technique. Desalination 249(2):571-576

Terfie TA, Asfaw SL (2015) Evaluation of selected wetland plants for removal of chromium from tannery wastewater in constructed wetlands, Ethiopia. African J Environ Sci Technol 9:420-427

Theophile F, Sako IB, Martin L, Fabrice MT, Akoa A (2011) Potential of Cyperus Papyrus in yard-scale horizontal flow constructed wetlands for wastewater treatment in Cameroon. Universal J Environ Res Technol 1(2):160

Torres P, Foresti E (2001) Domestic sewage treatment in a pilot system composed of UASB and SBR reactors. Water Sci Technol 44(4):247-253

Torretta V, Ferronato N, Katsoyiannis IA, Tolkou AK, Airoldi M (2017) Novel and conventional technologies for landfill leachates treatment: a review. Sustainability (Switzerland) 9(1):1-39

UN-HABITAT, (2008) Constructed Wetlands Manual. UN-HABITAT Water for Asian Cities Programme Nepal, Kathmandu

Von Sperling M (2015) Comparison of simple, small, full-scale sewage treatment systems in Brazil: UASB-maturation ponds-coarse filter; UASBhorizontal subsurface-flow wetland; vertical-flow wetland (first stage of French system). Water Sci Technol 71(3):329-336
Vymazal J (2005) Horizontal subsurface flow and hybrid constructed wetlands systems for wastewater treatment. Ecol Eng 25:478-490

Vymazal J (2007) Review: removal of nutrients in various types of constructed wetlands. Sci Total Environ 380:48-65

Vymazal J, Kropfelova L (2008) Wastewater treatment in constructed wetlands with horizontal sub-surface flow. Springer, Dordrecht

Wang Q, Hu Y, Xie H, Yang Z (2018) Constructed wetlands: a review on the role of radial oxygen loss in the rhizosphere by macrophytes. Water 10(6):678

Wijaya DS, Hidayat T, Sumiarsa D, Kurnaeni B, Kurniadi D (2016) A review on sub-surface flow constructed wetlands in tropical and sub-tropical countries. Open Sci J 1(2):1-11

Worku A, Tefera N, Kloos H, Benor S (2018) Bioremediation of brewery wastewater using hydroponics planted with vetiver grass in Addis Ababa, Ethiopia. Bioresoures Bioprocessing 5(1):39

Xu J, Zhao G, Huang X, Guo H, Liu W (2017) Use of horizontal subsurface flow constructed wetlands to treat reverse osmosis concentrate of rolling wastewater. Int J Phytorem 19(3):262-269

Zamora S, Marín-Muñíz JL, Nakase-Rodríguez C, Fernández-Lambert G, Sandoval L (2019) Wastewater treatment by constructed wetland ecotechnology: influence of mineral and plastic materials as filter media and tropical ornamental plants. Water 11(11):2344

Zeb BS, Mahmood Q, Jadoon S, Pervez A, Irshad M, Bilal M, Bhatti ZA (2013) Combined industrial wastewater treatment in anaerobic bioreactor posttreated in constructed wetland. BioMed Res Int. 2013.

Zhu H, Yan B, Xu Y, Guan J, Liu S (2014) Removal of nitrogen and COD in horizontal subsurface flow constructed wetlands under different influent $\mathrm{C} / \mathrm{N}$ ratios. Ecol Eng 63:58-63

\section{Publisher's Note}

Springer Nature remains neutral with regard to jurisdictional claims in published maps and institutional affiliations.

\section{Submit your manuscript to a SpringerOpen ${ }^{\circ}$ journal and benefit from:}

- Convenient online submission

- Rigorous peer review

- Open access: articles freely available online

- High visibility within the field

- Retaining the copyright to your article

Submit your next manuscript at $\boldsymbol{\nabla}$ springeropen.com 